\title{
A Review of Intra- and Extracellular Antigen Delivery Systems for Virus Vaccines of Finfish
}

\author{
Hetron Mweemba Munang'andu and Øystein Evensen \\ Section of Aquatic Medicine and Nutrition, Department of Basic Sciences and Aquatic Medicine, Faculty of Veterinary Medicine and \\ Biosciences, Norwegian University of Life Sciences, Ullevalsveien 72, P.O. Box 8146, 0033 Oslo, Norway
}

Correspondence should be addressed to Hetron Mweemba Munangandu; hetron2002@yahoo.co.uk

Received 28 October 2014; Revised 8 April 2015; Accepted 9 April 2015

Academic Editor: Kurt Blaser

Copyright (๔) 2015 H. M. Munang'andu and Ø. Evensen. This is an open access article distributed under the Creative Commons Attribution License, which permits unrestricted use, distribution, and reproduction in any medium, provided the original work is properly cited.

\begin{abstract}
Vaccine efficacy in aquaculture has for a long time depended on evaluating relative percent survival and antibody responses after vaccination. However, current advances in vaccine immunology show that the route in which antigens are delivered into cells is deterministic of the type of adaptive immune response evoked by vaccination. Antigens delivered by the intracellular route induce MHC-I restricted CD8+ responses while antigens presented through the extracellular route activate MHC-II restricted CD4+ responses implying that the route of antigen delivery is a conduit to induction of B- or T-cell immune responses. In finfish, different antigen delivery systems have been explored that include live, DNA, inactivated whole virus, fusion protein, virus-like particles, and subunit vaccines although mechanisms linking these delivery systems to protective immunity have not been studied in detail. Hence, in this review we provide a synopsis of different strategies used to administer viral antigens via the intra- or extracellular compartments. Further, we highlight the differences in immune responses induced by antigens processed by the endogenous route compared to exogenously processed antigens. Overall, we anticipate that the synopsis put together in this review will shed insights into limitations and successes of the current vaccination strategies used in finfish vaccinology.
\end{abstract}

\section{Introduction}

The central hallmark of vaccination is to prime the adaptive immune system to develop immune responses that will protect the host organism upon a second encounter with the same pathogen. However, priming the adaptive immune system requires activation of naïve $\mathrm{B}$ - and T-lymphocytes into effector cells that translate into protective immunity. While studies on the immunological basis of vaccine protection have for a long time focused on humoral and cellular responses as measures of protective immunity, growing evidence shows that the mode by which antigens are presented to B- or Tlymphocytes has a significant influence on the outcome of adaptive immune responses induced by vaccination which is also influenced by the mode in which antigens are administered to host cells $[1,2]$. Put together, these elements drive vaccine development into a cross-talk between vaccinology and immunology in which vaccine design and its delivery (vaccinology) on one hand have to be optimized in order to gain an effective immune response (immunology) on the other. Hence, optimization of antigen design and its delivery into host cells is a prerequisite to inducing an optimal protective immune response.

Unlike B-lymphocytes, which are precursors of antibody secreting cells that can recognize antigens through primed antigen presenting cells (APCs)/activated B-cells [1], T-cell receptors (TCRs) can only "see" antigens that are processed and presented by APCs. TCRs recognize antigen peptides bound on the surface of MHC molecules [2]. Endogenous peptides derived from intracellular sources such as replicating virus are synthesized and processed for presentation to naïve CD8 T-cells by MHC-I molecules while exogenous peptides derived from extracellular sources are processed and presented to naïve CD4 T-cells by MHC-II molecules. 
An alternative mechanism that permits some extracellular antigens to activate naïve CD8 T-cells called cross presentation exists which occurs via the MHC-I pathway $[3,4]$. For antigens delivered via the endosomal route, proteosomes degrade soluble antigens after ubiquitination which have been synthesized in the cytosol or escaped to the endoplasmic reticulum (ER) by cross presentation [5]. Thereafter, the processed antigens are released after proteosomal degradation to generate peptides that are transported into the ER by the transporter-associated antigen processing (TAPs) $[5,6]$. Once in the ER, the antigenic peptides are loaded onto MHC-I molecules for presentation on the cell surface where they initiate the activation of naive CD8 T-cells into effector cytotoxic T-lymphocytes (CTLs) [7-9]. In the case of antigens delivered by the exogenous route, lysosomes degrade endocytosed antigens after endosomal fusion with lysosomes [10]. In general, lysosomes can degrade complex structures such as whole viral particles that are delivered to them via endocytosis by the extracellular route [11]. Presentation of processed peptides by endosomal degradation leads to maturation of APCs into professional APCs which is characterized by expressing MHC-II molecules and antigen specific signaling molecules such CD40L, CD80, and CD86. The resulting professional APCs are the prime initiators of adaptive immune responses that activate naïve $\mathrm{T}$-cells into effector cells through the MHC-peptide complexes and immune modulation molecules. Therefore, it follows that, for a vaccine antigen to turn naïve B- or T-lymphocytes into "protective" cell, there has to be an efficient antigen delivery system that stimulates the activation of cell of the adaptive immune system.

Although studies on antigen presentation in fish immunology have gained prominence in recent years [12-14], there is still limited research on activation of cells of the adaptive immune system by APCs, which precludes our understanding of the role of innate immunity in optimizing vaccine performance. Despite that, several studies have been carried out trying to deliver viral antigens into different compartments of fish cells. Hence, in this review we provide an overview of these delivery systems and based on this approach we highlight the different immune responses induced by antigens delivered by the intracellular route compared to antigens delivered by the extracellular route. In addition, we also highlight the differences in vaccine efficacy from fish immunized using antigens delivered by the exogenous route compared to fish vaccinated using the endogenous route. Overall, we anticipate that the synopsis of different antigen delivery systems put together in this review will shed new insights into limitations and successes of the current vaccination strategies used in fish vaccinology.

\section{Fish Antigen Presenting Cells, Adaptive Immune Cells, and Their Receptors}

In mammals, antigen presentation is carried out by different cell types that include monocytes, macrophages, and dendritic cells [15]. These cells possess pattern recognition receptors (PRRs) that recognize and bind to pathogen associated molecular patterns (PAMPs) known as "danger signals" on pathogens [16]. Upon binding to PAMPs using PRRs, monocytes mature into macrophages while immature dendritic cells (DCs) also transform into mature dendritic ones to become professional APCs, which induce the expression of proinflammatory cytokines that attract more APCs to the sites of antigen deposition [15, 17]. Upon encounter with the APCs, naive B- and T-cells undergo maturation to become memory cells capable of recognizing the antigens in subsequent encounters thereby creating the basis acquired immunity.

In teleosts fish, APCs known to possess PRRs having the capacity to bind to different PAMPs on pathogens have been described in different species and these include monocytes, macrophages, and dendritic-like cells [13, 18-26]. In addition fish B-cells have been shown to carry out antigen presentation apart from their role as antibody secreting cells [27]. As a result, in vitro methods for culturing fish monocytes, macrophages, and dendritic-like cells have been developed which makes it easy to study antigen presentation using cell cultures $[18,19,24,25]$. It is interesting to note that TAP genes comparable to those seen in mammals have been identified and mapped to MHC regions in different cartilaginous and bony fish species suggesting that similar mechanisms of endogenous antigen processing seen in higher vertebrates also exist in teleosts fish [28-31]. Unlike in mammals where APCs carrying processed antigens migrate to the lymph nodes [32], in fish APCs carrying antigens migrate to the head, kidney, and spleen [13], which are the major lymphoid organs [33]. Apart from lymphoid organs, APCs have been detected in other organs such as the gills, skin, and intestines in fish $[34,35]$. In addition, different phagocytic cell types have been characterized in fish although their antigen presentation capabilities have not been investigated [36, 37].

Similar to their mammalian counterparts, fish APCs possess a wide range of surface markers that include CD80/CD86, CD83, CD209, MHC-I, and MHC-II proteins [20, 38-41]. In fish, CD83 has been shown to be an activation marker for macrophages [42] and dendritic-like cells [23]. Apart from CD83, other surface markers identified for fish dendritic-like cells include CD208/lysosomal associated membrane protein (LAMP3) [43]. Recently, Zhu et al. [44] showed that fish B-cells act as pivotal APCs in priming the adaptive immune system using CD80/CD86 molecules. In another study, Abós et al. [45] showed upregulation of MHC-II genes that coincided with upregulation of CD80/CD86 genes in a nonlethal infection (no cytopathic effects observed) of viral hemorrhagic septicemia virus (VHSV) in IgM+ cells which consolidates the notion that fish B-cells use CD80/CD86 molecules to activate the adaptive immune system using the MHC-II pathway [44, 46].

As shown in Table 1, all four T-cell receptor chains $(\alpha$, $\beta, \gamma$, and $\delta$ ) required for binding to APCs together with the four chains $\left(\gamma^{-}, \delta-, \mathcal{E}^{-}\right.$, and $\zeta$-chain) of the CD3 coreceptor complex required for $\mathrm{T}$-cell activation in mammals have been reported in fish. In addition, the T-cell costimulatory marker CD28 and the negative regulatory marker CTLA-4, which bind to CD80 and CD86 receptors on APCs, have 
TABLE 1: Fish antigen presenting and adaptive immunity cell receptors.

\begin{tabular}{|c|c|c|}
\hline Protein & Selected examples of fish species & Reference \\
\hline \multicolumn{3}{|c|}{ (1) Antigen presenting surface markers and MHC molecules } \\
\hline CD80 (B7.1) & Zebrafish, rainbow trout & {$[44,159]$} \\
\hline CD83 (7.2) & Zebrafish, turbot, Atlantic salmon & {$[44,159-161]$} \\
\hline CD86 & Zebrafish, rainbow trout & {$[44,159]$} \\
\hline CD209 & Zebrafish & {$[162]$} \\
\hline MHC-I & Orange spotted grouper, sea bass, grass carp & {$[49,163,164]$} \\
\hline MHC-II & Zebrafish, lake trout, & {$[159,165]$} \\
\hline \multicolumn{3}{|c|}{ (2) T-cell receptors, costimulatory and activator molecules } \\
\hline $\mathrm{CD} 3 \gamma$ & Atlantic salmon & {$[166]$} \\
\hline $\mathrm{CD} 3 \varepsilon$ & Atlantic salmon & {$[166]$} \\
\hline $\mathrm{CD} 3 \zeta$ & Atlantic salmon & {$[166,167]$} \\
\hline $\mathrm{CD} 3 \delta$ & Rainbow trout, Atlantic salmon & {$[166,168,169]$} \\
\hline TCR $\alpha$ & Rainbow trout and Japanese flounder & {$[170,171]$} \\
\hline $\operatorname{TCR} \beta$ & Rainbow trout and Japanese flounder & {$[170,171]$} \\
\hline TCRY & Japanese flounder & {$[171]$} \\
\hline $\mathrm{TCR} \sigma$ & Japanese flounder & {$[171]$} \\
\hline $\mathrm{CD} 28$ & Rainbow trout & {$[47,48]$} \\
\hline CTLA & Rainbow trout & {$[47,48]$} \\
\hline CD40L & Atlantic salmon and Japanese flounder & {$[65,172]$} \\
\hline \multicolumn{3}{|c|}{ (3) T-cells } \\
\hline $\mathrm{CD} 8 \alpha$ & Rainbow trout, Atlantic salmon & {$[51,143,173]$} \\
\hline $\mathrm{CD} 8 \beta$ & Atlantic salmon, Atlantic salmon & {$[143,169]$} \\
\hline $\mathrm{CD} 4$ & Atlantic salmon & [169] \\
\hline \multicolumn{3}{|c|}{ (4) Immunoglobulins } \\
\hline $\operatorname{IgM}$ & Atlantic salmon, rainbow trout & {$[56,174,175]$} \\
\hline $\operatorname{IgD}$ & Atlantic salmon, rainbow trout & {$[59,174]$} \\
\hline IgT & Rainbow trout, Atlantic salmon & {$[58,62]$} \\
\hline IgZ & Zebrafish & {$[176]$} \\
\hline
\end{tabular}

also been characterized in fish $[47,48]$. As for CD8 Tcells, two subsets have been characterized, namely, $\mathrm{CD} 8 \alpha$ and $\mathrm{CD} 8 \beta$, from different fish species of which CD $8 \alpha$ has been the most widely used marker for T-cell activation in different studies [49-51]. Moreover, cell mediated cytotoxicity against allogeneic targets and virus infected cells has been reported by different scientists [50, 52-54]. Put together these observations suggest that fish $\mathrm{T}$-cells possess surface receptors essential for the binding to APCs comparable to those found in mammals and that activation of T-cells into effector cytotoxic T-lymphocytes (CTLs) could be based on similar mechanisms to those seen in mammals.

There are three immunoglobulin isotypes characterized in fish, this far, and these include $\operatorname{IgM}[55,56]$ and $\operatorname{IgD}[55,57]$ also present in mammals while the recently identified $\operatorname{IgT}$ [58] is only found in fish where it exists as membrane bound and secreted form in serum $[59,60]$. IgM is the most abundant isotype in serum where it is estimated to be $>1000$-fold higher than IgT $[61,62]$. In addition, IgM has been detected in the mucus of the skin, gills, and intestines although its levels in these organs are far much lower than levels detected in serum
$[61,62]$. On the contrary, IgT is predominantly found in the mucus of the skin, gut, and intestines [61-63] where it is $>100$ fold higher than levels detected in sera [61]. It is interesting to note that the costimulatory marker CD40L mostly expressed in activated CD4+ T-cells, which binds to the CD40 receptors on APCs in order to activate B-cell proliferation [64], has been characterized in fish [65]. In addition, transcription factors involved in specification of CD4 T-cells into different T-helper (Th) subtypes have also been characterized, which include T-bet [66, 67], GATA-3 [68-70], and ROR $\gamma[71,72]$ for the differentiation of naïve CD4 T-cells into Th1, Th2, and Th17 subtypes, respectively. In addition, several cytokines linked to specification of CD4 T-cell into different subtypes have been characterized and these include IL-2, IL-4, IL6, IL-10, IL-12, IFN $\gamma$, IL-15, IL-21, IL-22, and TGF $\beta$ [40, $41,73,74]$. Overall, the characterization of different APCs and adaptive immune cells together with their receptors and regulatory cytokine presented here suggests that teleosts fish antigen presentation mechanisms could be comparable to those used by mammals suggesting that antigen presentation mechanisms have been conserved across the vertebrate taxa. 


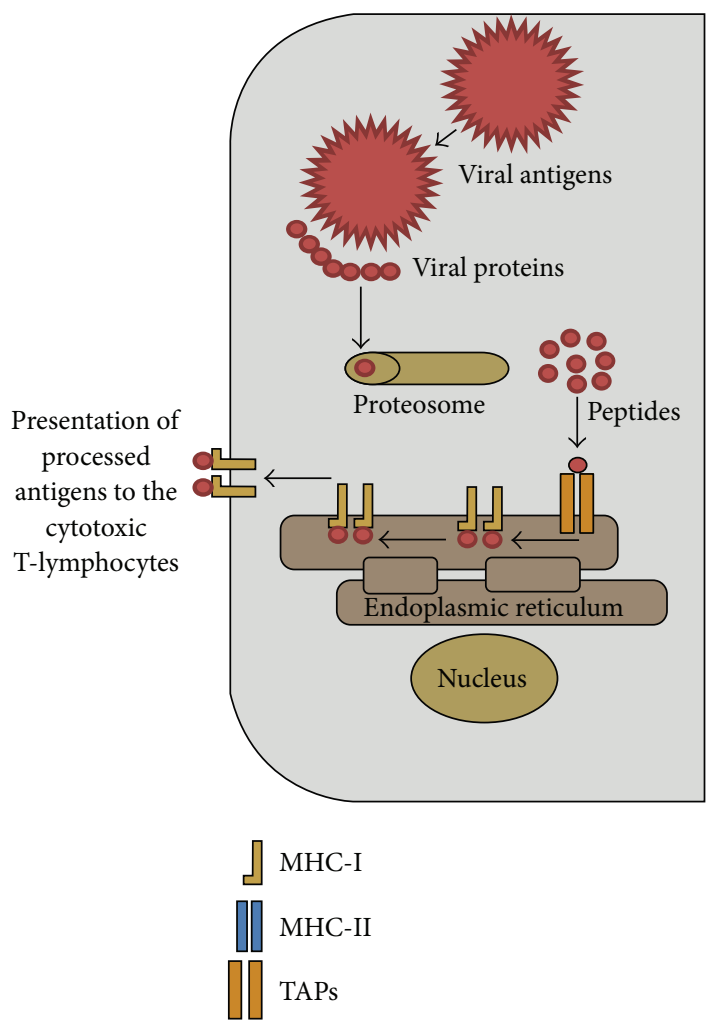

(a)

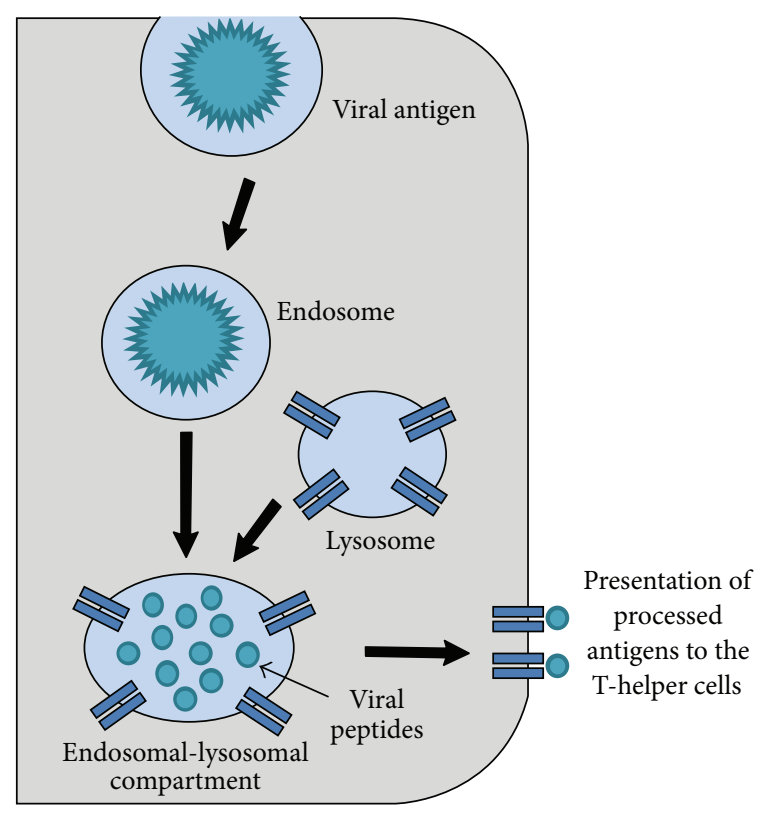

MHC-I

MHC-II

TAPs

FIGURE 1: The endogenous and exogenous pathways of viral antigen entry into host cells. (a) Endogenous pathway shows viral antigens that enter the host cells by the intracellular route. Once internalized, the viral antigens are degraded into peptides by proteasomes. Thereafter, the processed antigenic peptides are transported via the transporter associated with antigen presentation (TAPs) to the endoplasmic reticulum (ER) where they are loaded onto MHC-I molecules for presentation at the cell surface to CD8+ T-cells. (b) Exogenous pathway shows antigens that enter the antigen presenting cells (APCs) via the extracellular route which results in internalization of the antigens in the endosomes. Thereafter, the endosomes fuse with the lysosomes to form the endosomal-lysosomal compartments that have MHC-II complexes. In the endosomal-lysosomal compartments, the antigens are degraded into peptides followed by packaging of the peptides onto MHC-II complexes. Thereafter, the MHC-II complexes carrying the peptides are transported to the cell surface for presentation of the antigenic peptides to the CD4 T-cells.

\section{Intracellular Antigen Delivery Systems}

Intracellular antigen delivery systems involve immunization strategies that administer the vaccine antigens into the cytoplasm (Figure 1) and these include the following.

3.1. Live Vaccines. Live vaccines use attenuated viruses or recombinant antigens encoded by live virus vectors that have the capacity to replicate in host cells with attenuated pathogenicity lacking the ability to cause disease. As analogues of pathogenic viruses, they engage with the cell membrane by binding to surface receptors using epitopes similar to their native virus, thereby gaining entry into endosomal structures and the cytosol where they use the host cell machinery to replicate. Consequently, the processed antigens are presented on the cell surface by MHC-I molecules while soluble antigens expressed by replicating virus are engulfed by APCs to induce humoral immune responses (Figure 1). Hence, live vaccines induce both cellular and humoral immune responses.
In general, different scientists have reported the induction of CTL responses in fish $[52,53,75]$. Utke et al. [76] showed activation of the CTLs by viral hemorrhagic septicemia virus (VHSV) infection in rainbow trout, while we [51] recently showed activation of eomesodermin, a transcription factor involved in activation of CD8 $\alpha$ cells in Atlantic salmon exposed to infectious pancreatic necrosis virus (IPNV). Similarly, Chang et al. [49] showed activation of CD8 $\alpha$ cells after exposing orange spotted grouper (Epinephelus coioides) to nervous necrosis virus (NNV). Flow cytometry analysis of the spleen cells from fish exposed to NNV showed increased mean fluorescent intensity of the CD $8 \alpha$ cells and peripheral blood leukocytes (PBLs) which were linked to increased cytotoxicity and $\mathrm{MHC}-\mathrm{I}$ restriction of the sorted lymphocytes by recombinant $\mathrm{CD} 8 \alpha$ antibodies. Several fish species have shown upregulation of MHC-I and -II molecules [49, 77-80] as well as expression of high antibody levels after exposure to viral infections $[81,82]$ suggesting that attenuated viruses administered as live vaccines could evoke both cellular and humoral immunity. Based on these observations, several 
TABLE 2: Live vaccines.

\begin{tabular}{|c|c|c|c|c|c|}
\hline Virus & Abbreviation & Fish host & Mode of attenuation & Protection & Reference \\
\hline Cyprinid herpesvirus subtype 3 & CyHV-3 & Carp & Natural selection & High & [177] \\
\hline \multirow{5}{*}{ Viral hemorrhagic septicemia } & VHSV & Rainbow trout & Naturally attenuated & High & {$[178]$} \\
\hline & VHSV & Rainbow trout & Naturally attenuated & High & {$[84]$} \\
\hline & VHSV & Olive flounder & Recombinant (RG) modification & High & [179] \\
\hline & VHSV & Rainbow trout & Recombinant (RG) modification & High & {$[180]$} \\
\hline & VHSV & Zebra fish & Recombinant (RG) modification & High & {$[181]$} \\
\hline \multirow{5}{*}{ Infectious hematopoietic necrosis virus } & IHNV & Rainbow trout & Multiple serial passage & High & {$[86]$} \\
\hline & IHNV & Rainbow trout & Naturally attenuated & High & {$[83]$} \\
\hline & IHNV & Rainbow trout & Natural selection & High & {$[182]$} \\
\hline & IHNV & Rainbow trout & Recombinant (RG) modification & High & {$[91]$} \\
\hline & IHNV & Rainbow trout & Recombinant (RG) modification & High & {$[183]$} \\
\hline Infectious pancreatic necrosis virus & IPNV & Atlantic salmon & Avirulent strain/low dose & High & {$[82]$} \\
\hline Rock bream iridovirus & RSIV & Rock bream & Low temperature & High & {$[184]$} \\
\hline
\end{tabular}

attempts have been made to develop live viral vaccines for fish (Table 2) and some of the strategies explored this far are outlined below.

3.1.1. Natural Selection of Avirulent Strains. Roberti et al. [83] discovered a naturally attenuated mutant of infectious hematopoietic necrosis virus (IHNV) that conferred protection against IHNV in rainbow trout although the vaccine resulted in causing low level mortality after challenge. Adelmann et al. [84] used an oral vaccine against VHSV obtained from a naturally attenuated live virus selected using monoclonal antibodies. In their study, they [84] showed high expression levels of MHC-II and CD4 mRNAs. In addition, they detected antibody responses that were linked to significant protection in rainbow trout after challenge.

3.1.2. Attenuation by Serial Passages. An attenuated IHNV vaccine was developed at Oregon State University by multiple passages using a rainbow trout isolate propagated using the steelhead trout cell culture $[85,86]$. The vaccine showed high protection $(95 \%)$ in vaccinated Chinook salmon while mortality in control fish reached $90 \%$. Although the vaccine was highly protective in Chinook salmon, when used in rainbow trout it showed significant mortality and as such it was stopped $[87,88]$. Since the Ab strain of infectious pancreatic necrosis virus (IPNV) was found to be less virulent than the West Buxton, Sp, or Jasper strain, Dorson et al. [89] attempted to develop an attenuated strain of IPNV from the Ab strain after several passages on RTG cells. Neither the serially passaged nor the original $\mathrm{Ab}$ strain conferred protection.

3.1.3. Reverse Genetics. Reverse genetics has been used in fish vaccinology to generate avirulent strains for use as live vaccines. For example, recombinant IHNV having a deletion of the NV gene resulted in irreversible attenuation of the wild type virulent strain resulting in the induction of high protection levels in rainbow trout [90]. In another study, recombinant IHNV generated by replacing the NV gene with green fluorescent protein (GFP) or substituting the IHNV G-gene with the G-gene of VHSV induced heterologous protection in rainbow trout [91]. For IPNV, reverse genetics was used to generate an avirulent strain for use as a live vaccine against the wild type strain by substituting amino acids on positions 217 and 221 of the VP2 capsid [92]. These studies showed that the strain encoding the $\mathrm{T}_{217} \mathrm{~A}_{221}$ motif caused high mortality in Atlantic salmon while the strain encoding the $\mathrm{P}_{217} \mathrm{~T}_{221}$ motif was avirulent and linked to subclinical infections [93]. Infecting Atlantic salmon with high and low virulent strains at a nonpermissive physiological state (presmoltification stage) did not result in mortality. When the vaccinated fish were challenged at smolt stage (permissive) the avirulent strain was less immunogenic than the virulent vaccine strain [82]. In addition, we observed that the avirulent strain reverted to virulence under stress conditions [37, 94]. In general, the fear of reversion to virulence has been the major hindrance for the licensure of live vaccines in aquaculture.

3.2. DNA Vaccines. The strategy of DNA vaccination is based on the principle that the encoded immunogenic protein is injected into the muscle or other tissues where it enters the host cells and directs the synthesis of its polypeptide antigen from the plasmid vector. Once transfected into host cells, transcribed antigens replicate in the cytosol using the endogenous pathway while soluble or secreted antigens are phagocytized by APC and gain access into the exogenous pathway (Figure 1). In principle, DNA vaccines result in the in vivo synthesis of antigenic proteins using the host cell machinery in a manner identical to natural virus infection in the case of DNA vaccines made for viral diseases. This culminates into antigenic proteins expressed by plasmid DNA gaining access to both the exogenous and endogenous pathways in the activation of both humoral and cellular mediated immune responses.

Boudinot et al. [95] demonstrated the intracellular delivery of the plasmid DNA encoding the recombinant G protein 
TABLE 3: DNA vaccines explored in fish.

\begin{tabular}{|c|c|c|c|c|c|c|}
\hline Classification & Virus family & Pathogen & Abbreviation & Antigen & Protection $^{*}$ & Reference \\
\hline \multirow{2}{*}{ DNA viruses } & Iridovirus & Red sea bream iridovirus & RSIV & Major capsid & Moderate & {$[185]$} \\
\hline & Herpesviridae & Channel catfish virus (CCV) & $\mathrm{CCV}$ & ORF $6 \& 59$ & Low & [186] \\
\hline \multirow{8}{*}{ RNA virus } & Rhabdoviridae & Viral hemorrhagic septicemia virus & VHSV & $\mathrm{G}$ & High & {$[95]$} \\
\hline & Rhabdoviridae & Infectious hematopoietic necrosis virus & IHNV & G & High & {$[98,187,188]$} \\
\hline & Rhabdoviridae & Spring viremia of carp virus & SVCV & G & High & {$[189,190]$} \\
\hline & Rhabdoviridae & Hirame rhabdovirus & HRV & G & High & [191] \\
\hline & Birnaviridae & Infectious pancreatic necrosis virus & IPNV & SegA/VP2 & Moderate & {$[103,140]$} \\
\hline & Orthomyxoviridae & Infectious salmon anemia virus & ISAV & $\mathrm{HE}$ & Moderate & {$[192]$} \\
\hline & Togaviridae & Salmon alphavirus subtype 3 & SAV-3 & E2 & Moderate & [157] \\
\hline & Nodaviridae & Atlantic halibut nodavirus & ANHV & Capsid & Low & {$[193]$} \\
\hline
\end{tabular}

${ }^{*}$ Protection was determined by postchallenge relative percent survival (RPS).

of VHSV inside the muscle cells of vaccinated rainbow trout. Intracellular detection of the G-protein was shown up to 45 days at the injection sites. Transcription of the G-protein was demonstrated by detection of mRNA in muscle tissue extracts, which was linked to expression of high antibody and MHC-II mRNAs levels. In another study, Utke et al. [96] showed activation of the CTLs following immunization using the G-protein of VHSV in rainbow trout. In their study, they [96] used PBLs collected from fish immunized with a DNA vaccine encoding the recombinant $\mathrm{G}$-protein of VHSV and showed that PBLs from vaccinated fish killed the VHSV MHC-I matched RTG-2 cells indicating that the G-proteins had the capacity to induce CTL responses in vaccinated fish. They also showed the homing of leukocytes to the injection site suggesting that cells expressing the recombinant G-protein had a chemoattractant effect. This observation was recently supported by Castro et al. [97] who showed that Blymphocytes, both $\operatorname{IgM}^{+}$and $\operatorname{IgT}^{+}$cells, represent one of the major cell types infiltrating the injection sites expressing the G-protein of VHSV. In their study, they showed upregulation of CXCR3B, a receptor for CXCL11, together with CK5B and CK6 chemokines, which could play chemotactic roles in the early recruitment of B-cells at the injection sites. Put together, these studies show that the intracellular expression of proteins transcribed from DNA vaccines in fish cells leads to homing of leukocytes and B-cells to injection sites with possible involvements of chemoattractant chemokines. Further, these studies suggest that antigens delivered by this endogenous route evoke both the humoral and cellular mediated immune responses in vaccinated fish.

Finally, it is important to point out that immunization using DNA vaccines exhibits many advantages over the live and inactivated vaccines. Intracellular synthesis of the antigenic proteins poses no danger of reversion to virulence and does not require inactivation of viruses using toxic substances. High expression levels of humoral and cellular responses can be achieved at low doses as shown by Corbeil et al. [98] that nanogram quantities of a DNA vaccine protected rainbow trout against IHNV infection after challenge. In addition, intracellular synthesized antigens tend to fold in their native conformation and correctly glycosylated displaying the neutralizing epitopes in a similar pattern to the native virus [99]. In terms of genetic engineering, combinational approaches can easily be adopted. For example, the use of molecularly encoded cytokine adjuvants like IL-2 in DNA engineered vaccines has shown the ability to enhance DNA delivery and increase the duration and magnitude of plasmid DNA expression in vivo [100]. Jimenez et al. [101] coinjected recombinant IL-8 with plasmid DNA encoding the G-protein of VHSV in rainbow trout and showed massive infiltration of neutrophils at the injection site linked to upregulation of proinflammatory cytokines. Table 3 shows the DNA vaccines explored for use in fish, this far, of which only the DNA vaccine for IHNV has been licensed in Canada (Novartis Ltd.).

3.3. Fusion Protein Vaccines. This mode of antigen delivery which has been referred to as "the first class ticket to induction of MHC-I responses" relies on receptor mediated internalization of viral antigens to the ER followed by retrograde translocation into the cytosol [102]. Only a few studies have explored this delivery system in fish vaccinology, this far $[103,104]$. Li-Li et al. [104] constructed a fusion protein vaccine made by fusing the VP2-VP3 polyprotein of IPNV with the exotoxin of Lactobacillus casei, which resulted in reduced viral loads in vaccinated rainbow trout after challenge while in our group we constructed a fusion protein vaccine made by fusing the VP2 of IPNV with the Pseudomonas aeruginosa exotoxin A (EP) [103]. The exact mechanisms in which viral antigens are translocated into the cytosol are dependent on three bacterial proteins as illustrated from the PE fusion protein in Figure 2. The PE protein has three functional domains, namely, the receptor binding domain-I, transmembrane targeting domain-II, and the toxic moiety domain-III. Domain-I binds to the $\alpha 2$ macroglobulin receptor on the cell surface. After binding to domain-I the ligand-receptor complex is internalized through the receptor mediated endocytosis. After enzymatic cleavage by the protease furin in the endosome, the protein fragment encoding domains-II and -III is delivered into the Golgi by the ER retrograde transport and further into the cytosol using domain-II, which is responsible for transmembrane translocation of the toxin proteins into the cytoplasm. 


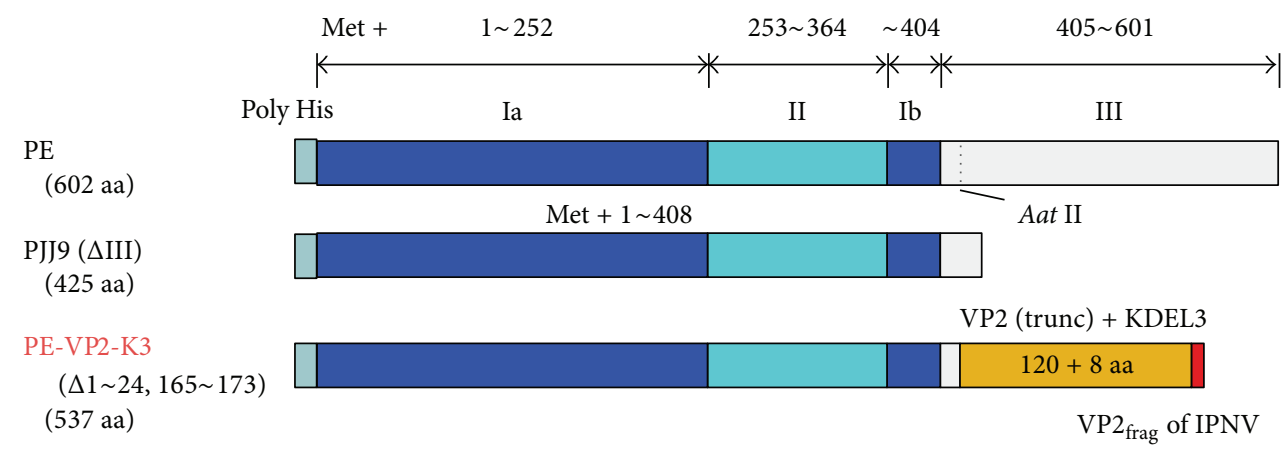

Figure 2: The fusion of the VP2- of IPNV to the Pseudomonas aeruginosa exotoxin A (PE). PE shows a 602 aa exotoxin for Pseudomonas aeruginosa made of three domains. Domain Ia (blue) located on 1-252 aa followed by domain II (green) on the location 253-364 aa, domain Ib (blue) located on 365-404 aa, and finally domain III on the extreme end located on 405-601 aa. PJJ9 ( $\Delta \mathrm{III})$ is a 425 aa long intermediate phase in which the toxic moiety of domain III has been cleaved. PE-VP2-KE is the final construct in which the toxic moiety of domain III has been replaced with the truncated VP2 (yellow) immunogenic protein of infectious pancreatic necrosis virus (IPNV). Note that the VP2 is attached to the KDEL3 signaling peptide (red).

As shown in Figure 2, domain-III, which is toxic to cells, is eliminated and is replaced with the immunogenic protein (VP2) of IPNV bound to the KDEL signaling peptide. The purpose of including the KDEL signaling peptide in the final construct (PE-VP2-KDEL) is that it enables the binding of the whole construct to the Golgi membrane KDEL-receptor. Once bound to the Golgi membrane receptor, the ligandreceptor complex is packaged into vesicles for retrograde transport back to the ER where processed peptides are packaged on MHC-I molecules for presentation on the cell surface. In our studies, we employed the PE-VP2-KDEL fusion protein to deliver the VP2 immunogenic protein of IPNV intracellularly as a vaccine. Although we did not assess the CTL responses induced by this antigen delivery system, our findings show that these vaccines were able to induce a low level antibody response suggesting that antigens delivered using this method could gain access to induction of humoral responses in vaccinated fish. However, there is a need for detailed investigation to determine the role of CTL responses induced by this mode of antigen delivery in vaccinated fish.

3.4. Nanoparticle Vaccines. Polymeric nanoparticles formulated from biodegradable polymers have been widely explored as carriers for controlled delivery of vaccine antigens $[105,106]$. This system can potentially deliver antigens to the desired location at predetermined rates and durations to generate an optimal immune response [107]. For example, Tian et al. [108-110] and Zheng et al. [111] showed that lymphocytic disease virus (LCDV) encapsulated in particles sustained a much longer release of the DNA antigen than naked DNA injected in Japanese flounder. In addition, carriers protect the antigen from degradation until release as shown by Rajeshkumar et al. [112] that encapsulated DNA antigens were protected from degradation by DNAase for vaccines used in the Asian sea bass (Lates calcarifer).

To deliver the antigens into host cells, nanoparticle materials are internalized by endocytosis [113]. To deliver the antigens into the cytosol, the release of antigens from the acidic endosomes requires membrane disruptive agents, which release the internalized proteins into the cytosol. Therefore, encapsulation carriers should include membrane penetrating peptides and polymers that disrupt the membranes when the $\mathrm{pH}$ declines in the endosomes. For example, Standley et al. [114] made acid degradable nanoparticles, which were designed to release encapsulated proteins in a $\mathrm{pH}$-dependent manner. In their study, they made nanoparticles that were stable at $\mathrm{pH} 7.4$ but quickly degradable at $\mathrm{pH} 5.0$ in the acidic endosomal environment enabling the release of antigens into the cytosol, ultimately resulting in upregulation of MHC-I. Another method explored is the use of amphiphilic polymers [115-117], which also have $\mathrm{pH}$ dependent membrane disruptive properties protonated at the endosomal $\mathrm{pH}$ range $[115,118]$. Upon reduction of the endosomal $\mathrm{pH}$, these particles increase their hydrophobicity to facilitate the disruption and penetration of the endosomal membranes culminating in the release of antigens in the cytosol. These amphiphilic polymers have been shown to increase $\mathrm{CD} 8+$ responses and to improve vaccine potency [119]. In summary, these studies show that nanoparticle antigen delivery systems can be designed to deliver antigens through the intra- or extracellular routes to evoke immune responses linked to the MHC-I or -II pathways.

Studies in higher vertebrates have shown that APCs easily carry out phagocytosis of nanoparticles and microparticles between $150 \mathrm{~nm}$ and $4.5 \mu \mathrm{m}[120,121]$ with the optimal size for phagocytosis being $500 \mathrm{~nm}$ [122] while monocytes have been shown to easily phagocytose nanoparticles $>100 \mathrm{~nm}$ [123]. And, as pointed out by Gutierro et al. [124], nanoparticles that encapsulate antigens resemble pathogens in terms of their uptake into host cells by mirroring the route of pathogen uptake and the immune response triggered after nanoparticle uptake. Fehr et al. [125] and He et al. [120] have also pointed out that nanoparticles can also be used to carry antigens on their surface which would serve as a good stimulant for the induction of B-cell responses. Although antigen delivery using nanoparticle vaccines has been well 
TABLE 4: Nanoparticle vaccines.

\begin{tabular}{lccccccc}
\hline Virus & Virus & Fish host & Admin & Antigen & Type & Protection* & Reference \\
\hline Lymphocytic virus & LCDV & Japanese flounder & Oral & Plasmid DNA & PLGA & High & {$[194]$} \\
Infectious hematopoietic necrosis virus & IHNV & Rainbow trout & Oral & Plasmid DNA & PLGA & Low & {$[195]$} \\
Infectious pancreatic necrosis virus & IPNV & Atlantic salmon & Injection & IWV & PLGA & Low & {$[127]$} \\
Infectious pancreatic necrosis virus & IPNV & Atlantic salmon & Injection & IWV & PLGA & Low & {$[103]$} \\
White syndromes spot virus & WSSV & Shrimp & Oral & Plasmid DNA & Chitosan & ND & {$[112]$} \\
White syndromes spot virus & WSSV & Shrimp & Oral & Plasmid DNA & Chitosan & ND & [196] \\
\hline
\end{tabular}

${ }^{*}$ Protection was determined by postchallenge relative percent survival (RPS). ND = not done (not tested for protection).

studied in higher vertebrates, indications are that fish cells use similar mechanisms of antigen uptake from nanoparticle based vaccines. For example, Ruyra et al. [126] showed entry of liposome-based nanoparticles in zebrafish hepatocytes and trout macrophages by endocytosis. Upon entry, the nanoparticle laden cells initiated specific proinflammatory responses while Fredriksen and Grip [127] showed intracellular cytoplasmic localization of polylactic-coglycolic acid (PLGA) nanoparticles in TO-cells [24]. These findings support earlier observations, which showed that because PLGA particles are less hydrophilic than alginates, they are easily incorporated into host cells, which makes them suitable vehicles for delivering antigens into intracellular compartments [128131]. Recently, we [103] used PLGA nanoparticles to deliver inactivated whole viral particles of IPNV as a vaccine, which expressed low antibody levels comparable to those induced by inactivated whole virus (IWV) vaccines suggesting that delivery of antigens using PLGA nanoparticles has the ability to induce humoral immune responses in vaccinated fish. Although there are limited studies that categorically demonstrate the intracellular delivery of nanoparticle based vaccines in fish cells, Rajeshkumar et al. [112] were able to induce low level cytotoxicity (tested in vitro) using chitosan nanoparticle vaccines in Asian sea bass vaccinated against vibriosis (Listonella anguillarum). Table 4 shows that only a few studies have been carried out using nanoparticle based technologies to administer viral antigens in fish. In general, indications show that nanoparticle based vaccines have the potential to deliver antigens into different host cell compartments and thus that they can induce cellular and humoral immune responses in vaccinated fish. The efficacy of nanoparticle vaccines needs to be improved and explored in more detail.

\section{Extracellular Antigen Delivery Systems}

This approach involves antigen delivery systems that administer viral antigens into the extracellular compartments using the exogenous pathway (Figure 1).

4.1. Inactivated Whole Viral Vaccines. This mode of antigen delivery ensures that the antigenic protein is preserved in its native structure while the virus is rendered nonreplicative using chemical or physical methods. Given that inactivated whole virus (IWV) vaccines are nonreplicative, it follows that their antigens enter the host cells by the exogenous route and their processed peptides are presented to CD4 cells via the MHC-II pathway. And, as such, several studies have shown upregulation of MHC-II genes in response to vaccination using IWV vaccines [77, 132]. In terms of CD4 T-cell differentiation, IWV vaccines have been shown to predominantly activate genes linked to the T-helper 2 (Th2) responses [133]. For example, we showed upregulation of GATA-3, a transcription factor linked to activation of naïve $\mathrm{CD} 4$ cells into Th2 responses, when genes linked to activation of Th1 and CD8 T-cell responses were downregulated [51]. In this study, we showed a high correlation between GATA3 and antibody levels expressed against IPNV [51]. In terms of antibody responses, IWV vaccines [134] have been linked to high expression levels of $\operatorname{IgM}$ and $\operatorname{IgT}$ in vaccinated fish [135]. In our studies, we showed a high correlation between postchallenge reduction of mortality and systemic IgM levels, suggesting IgM levels could serve as a correlate of protection for IWV vaccines [81]. Overall, these studies strongly suggest that IWV vaccines are to be considered as exogenous antigens, mainly inducing humoral immune responses. Table 5 shows the major IWV vaccines explored in fish vaccinology this far.

4.2. Subunit Vaccines. The basic principle for this vaccination strategy is that the gene encoding the antigenic proteins is isolated from the native virus and transferred into a heterologous vector that is nonpathogenic for propagation. Table 6 shows the antigenic proteins identified for the major fish viral diseases and the different expression vectors used for propagation. In the case of VHSV and IHNV, production of subunit vaccines has focused on cloning the G-protein into heterologous vectors [136-138] while, for viruses such as IPNV, the strategy has been to clone the entire outer capsid encoding the protective epitopes, instead of protein segments coding the neutralizing epitopes in heterologous vectors [103, 139-141]. Subunit vaccines are nonreplicative and are delivered exogenously to host cells by the extracellular route (Figure 1). Similar to IWV vaccines, subunit vaccines induce humoral immune responses and upregulation of MHC-II genes [139, 142], which is consistent with observations in higher vertebrates in which it has been shown that immune responses induced by subunit vaccines are mainly dependent on the MHC-II pathway and that they elicit antibody responses [143]. Øvergård et al. [144, 145] showed a high correlation between reduction of viral 
TABLE 5: Inactivated whole virus vaccines explored in fish.

\begin{tabular}{|c|c|c|c|c|c|}
\hline Pathogen & Abbreviation & Virus family & Fish species & Protection & Reference \\
\hline Viral hemorrhagic septicemia virus & VHSV & Rhabdoviridae & Rainbow trout & High $^{*}$ & {$[197]$} \\
\hline Infectious hematopoietic necrosis virus & IHNV & Rhabdoviridae & Rainbow trout & High $^{*}$ & {$[198]$} \\
\hline Spring viremia of carp virus & SVCV & Rhabdoviridae & Carp & High $^{*}$ & [199] \\
\hline Infectious pancreatic necrosis virus & IPNV & Birnaviridae & Atlantic salmon & High $^{*}$ & {$[81,103]$} \\
\hline Salmon pancreas disease virus & SPDV & Togaviridae & Rainbow trout & $\operatorname{High}^{2}$ & [200] \\
\hline Red seabream iridovirus & RSIV & Iridovirus & Sea bass & High $^{*}$ & {$[201]$} \\
\hline Singapore grouper iridovirus & SGIV & Iridovirus & Grouper & High $^{*}$ & [202] \\
\hline Channel catfish virus & $\mathrm{CCV}$ & Herpesviridae & Catfish & Moderate/high* & [203] \\
\hline Cyprinid herpesvirus subtype- 3 & CyHV-3 & Herpesviridae & Carp & High $^{*}$ & [204] \\
\hline Nervous necrosis virus & NNV & Betanodaviridae & Grouper & $\operatorname{High}^{1}$ & [205] \\
\hline Nervous necrosis virus & NNV & Betanodaviridae & Sea bass & $\operatorname{High}^{1}$ & {$[206]$} \\
\hline Salmon anemia virus & SAV & Orthomyxoviridae & Atlantic salmon & High $^{*}$ & [207] \\
\hline
\end{tabular}

Protection measured by ${ }^{*}$ relative percent survival (RPS), ${ }^{1}$ protection against postchallenge virus infection, and ${ }^{2}$ pathology.

TABLE 6: Subunit vaccines.

\begin{tabular}{|c|c|c|c|c|c|c|}
\hline Virus & Abbreviation & Protein & Vector & Efficacy & Fish species & Reference \\
\hline \multirow{5}{*}{ Infectious pancreatic necrosis virus } & IPNV & VP2 & Escherichia coli & Low & Atlantic salmon & [103] \\
\hline & IPNV & VP2 & Yeast cells & Low & Rainbow trout & [139] \\
\hline & IPNV & $\mathrm{VP} 2 / 3$ & Lactobacillus casei & Low & Rainbow trout & {$[208]$} \\
\hline & IPNV & VP2 & Baculovirus & Low & Atlantic salmon & {$[141]$} \\
\hline & IPNV & VP2 & Semliki Forest virus & N/A & CHSE cells & [209] \\
\hline \multirow{5}{*}{ Viral hemorrhagic septicemia virus } & VHSV & G & Saccharomyces cerevisiae & - & Rainbow trout & {$[210]$} \\
\hline & VHSV & G & Escherichia coli & High & Rainbow trout & {$[197]$} \\
\hline & VHSV & G & Yersinia ruckeri & Moderate-high & Rainbow trout & {$[211]$} \\
\hline & VHSV & G & Baculovirus & high & Rainbow trout & {$[142]$} \\
\hline & VHSV & G & Edwardsiella tarda & Moderate & Olive flounder & {$[212]$} \\
\hline \multirow{7}{*}{ Infectious hematopoietic necrosis virus } & IHNV & G & Escherichia coli & Moderate & Rainbow trout & {$[138]$} \\
\hline & IHNV & G & Caulobacter crescentus & Low & Rainbow trout & {$[213]$} \\
\hline & IHNV & G & Baculovirus & Moderate & Rainbow trout & {$[214]$} \\
\hline & IHNV & $\mathrm{G}$ & Aeromonas salmonicida & Moderate-high & Rainbow trout & [137] \\
\hline & GCRV & VP4 & Escherichia coli & Moderate-high & Grass carp & {$[215]$} \\
\hline & GCRV & VP5, VP7 & Escherichia coli & Moderate & Grass carp & {$[216]$} \\
\hline & VER & Capsid & Escherichia coli & Low & Atlantic halibut & [217] \\
\hline
\end{tabular}

RNA and activation of CD4 markers in Atlantic halibut (Hippoglossus hippoglossus L.) immunized using a subunit vaccine for nodavirus. Although cross presentation of exogenously processed peptides from endosomes into the cytosol has been reported in higher vertebrates $[3,4]$, there is no study demonstrating cross presentation of peptides processed from endosomes into the cytosol for subunit vaccines in fish.

4.3. Virus-Like and Subviral Particle Vaccines. Structural proteins of most viruses self-assemble to forms capsids in different expression systems that resemble the native virus structure in size and morphology and, hence, they are referred to as "virus-like particles" (VLPs). For example, Liu et al. [146] made VLPs of nodavirus expressed in E. coli or Spodoptera frugiperda (Sf21) insect cells that formed small, nonenveloped $T=3$ quasi-symmetric particles [147, 148]. They showed that the capsid of malabaricus grouper nervous necrosis virus (MGNNV) spontaneously self-assembled into VLPs when expressed in Sf21 cells infected with a recombinant baculovirus [148]. These VLPs were indistinguishable from the native virus particles by electron microscopy and the $3 \mathrm{D}$ structure of the VLPs was resolved at $2.3 \mathrm{~nm}$ by cryomicroscopy [147]. Similarly, Fang et al. [149] produced VLPs that were devoid of the nucleoprotein but resembled the outer capsid of the native grass carp reovirus (GCRV). However, in some cases VLPs are formed from replication of surface particulate components that do not form the entire capsid, but they contain elements of the outer capsid 
TABLE 7: Subviral, immature, and virus-like particles used for fish vaccines.

\begin{tabular}{lcccccc}
\hline Virus & Classification & Protein & Cells/vector & Fish host & Protection & Reference \\
\hline NNV & VLP & Capsid & Escherichia coli & Orange spotted grouper & ND $^{*}$ & {$[153]$} \\
NNV & VLP & Capsid & Saccharomyces cerevisiae & Red spotted grouper & ND $^{*}$ & {$[218]$} \\
IPNV & VLP & VP2 & Baculovirus/insect larvae & Rainbow trout & Low & {$[219]$} \\
IPNV & IVP & VP2 & CHSE cells & Rainbow trout & ND* & {$[151]$} \\
IPNV & SVP & VP2 & Yeast cells & Rainbow trout & Low & {$[150]$} \\
IPNV & SVP & VP2 & Yeast cells & Rainbow trout & Low \\
GCRV & SVP & Capsid & Ctenopharyngodon idellus & Grass carp & ND & {$[139]$} \\
VNNV & VLP & Capsid & Baculovirus & European sea bass & High & {$[221]$} \\
NNV & VLP & Capsid & Baculovirus & Orange spotted grouper & High $^{*}$ & {$[148]$} \\
NNV & VLP & Capsid & Escherichia coli & Dragon and Malabar grouper & ND $^{*}$ & {$[146]$} \\
VHSV & Peptide & Nucleoprotein & & Rainbow trout & ND $^{*}$ & {$[136]$} \\
\hline
\end{tabular}

$\mathrm{ND}=$ Note done (No protection studies carried out).

* Only immune expression studies were carried out by enzyme linked immunosorbent assay (ELISA) or gene expression.

that are immunogenic. These protein structures are called "subviral particles" (SVPs). Both VLPs and SVPs do not contain the nucleoprotein and as such they are nonreplicative. Table 7 shows the VLPs, SVPs, and immature virus particles (IVPs) made from different fish viruses. As shown in Table 7 , different expression systems were used to make VLPs [139], SVPs [150], and IVPs [151] for IPNV.

Given the similarity to their native viral capsids, VLPs provide an excellent platform for displaying viral epitopes $[146,152]$. This property was demonstrated by Lai et al. [153] who produced VLPs for NNV expressed in E. coli and showed that NNV failed to infect the Asian sea bass cells that were exposed to the VLPs prior to infection, suggesting that the cell surface receptors were occupied by the VLP-epitopes blocking the wild type virus from entering the cells and thereby protected the cells from developing cytopathic effect (CPE) while control cells not exposed to VLPs developed full CPE. Liu et al. [146] showed that VLPs generated from NNV induced high antibody responses that lasted for more than five months, similar to those produced by the native wild type virus, which were correlated with long-term protection in vaccinated orange spotted grouper. Similarly, Lai et al. [153] produced VLPs in E. coli for NNV that expressed high antibody levels, which were correlated with IgM, MHC-II, and CD4 levels in vaccinated fish. These observations suggest VLPs induce the expression of CD4 responses through the MHC-II pathways in a similar pattern to those induced by subunit vaccines in Mammalia [154].

\section{General Discussion and Conclusion}

The most explored strategies for the delivery of antigens using the intracellular route in fish vaccinology involve the use of live and DNA vaccines. The use of DNA vaccines in fish has undergone intense investigation in the last decades as a substitute of replicative antigens for live vaccines. Although factors leading to higher performance of DNA vaccines for rhabdoviruses compared to other fish viral families have not been elucidated, similar observations seen in higher vertebrates show that DNA vaccines for rhabdoviruses are more protective $[155,156]$ than some of the DNA vaccines for other viral families. In general, replicative vaccines delivered via the intracellular route have been linked to activation of cellular and humoral immune responses in vaccinated fish, which makes these vaccines be more protective than nonreplicative vaccines delivered by the extracellular route.

For antigens administered by the extracellular route, several antigen delivery strategies have been explored in fish vaccinology, which include the use of IWV, subunit, SVP, VLP, and IMP vaccines. In general, all exogenous antigens induce humoral immune responses. In terms of cellular immunity, exogenous antigens were linked to expression of MHC-II and CD4 genes. However, new innovations such as the use of fusion protein and nanoparticles vaccines having the potential to deliver nonreplicative antigens into the cytosol are likely to induce CTL responses in vaccinated fish. The use of nanoparticle vaccines has attracted a lot of interest in the delivery of oral vaccines for fish production systems that require a boost vaccination when fish have been transferred in cages to the sea after prime immunization using parenteral vaccines at the freshwater stage. In general, IWV vaccines are superior to subunit vaccines given that they produce high antibody levels, which correlate with protection in vaccinated fish $[81,157]$. In addition, these vaccines have been shown to activate the expression of CD4 and Th2 genes that correlate with high antibody levels consolidating the common notion that exogenous antigens stimulate humoral immune responses orchestrated by Th2 cytokines [154].

Although we did not review the role of APC prime/ activated B-cells in antigen uptake and presentation to cells of the adaptive immune system in detail given the limited studies carried out on this topic in fish vaccinology, we can conclude that the different antigen delivery systems explored in fish this far deliver their antigens into the intra- and extracellular compartments and that they activate either the cellular or humoral immune response or both depending on the route of antigen delivery. As pointed out by Howarth and Elliot [158], the most protective vaccines are those that stimulate both the CD4+ and CD8+ T-cells responses and, as such, replicative vaccines such as the live and DNA 
TABLE 8: Comparison of the intra- and extracellular antigen processing parameters.

\begin{tabular}{lcc}
\hline Parameters & Intracellular antigen delivery & Extracellular antigen delivery \\
\hline Vaccine types & & Nostly replicative \\
Viability of antigens & Live and DNA vaccines & Nonreplicative \\
Examples of vaccine types & & IWV vaccines, subunit vaccines \\
Antigen uptake and presentation & Endogenous pathway \\
Pathway of uptake into host cells & Penetration of host cell membrane & Exogenous pathway \\
Antigen uptake and processing & Cytoplasm & Phagocytosis by APCs \\
Site of antigen deposition & MHC-I and MHC-II & Endosome/phagosome \\
Antigen presenting molecules & Proteosomal degradation & MHC-II \\
Mode of antigen processing & Endosomal degradation \\
Adaptive immunity & B- and T-lymphocytes & Humoral immune responses \\
Type of immune response induced & CD4 and CD8 T-cells & B-lymphocytes \\
Cell types involved & CD4 T-cells \\
T-cell subtypes & CTL killing of virus infected cells & Antibodies \\
Effector molecules/cells & Antibody-neutralization of virus & Antibody-neutralization of virus \\
Effector mechanisms & & \\
\end{tabular}

vaccines that stimulate both the MHC-I and -II pathways are likely to produce better protection in fish (Table 8). So far only the IHNV-DNA vaccine for use in Atlantic salmon in Canada is the only one licensed while live viral vaccines are feared to revert to virulence. Hence, the use of IWV vaccines which accounts for the largest proportion of licensed vaccines is likely to continue dominating the vaccine industry in aquaculture [81, 157]. Therefore, the search for better antigen delivery systems that stimulate both $\mathrm{CD} 4+$ and $\mathrm{CD} 8+$ responses that have the potential to induce long-lasting protective immunity has to continue. Overall, we anticipate that the synopsis of different antigen delivery systems presented here will shed new insights into the limitations and successes of the current immunization strategies used in fish vaccinology.

\section{Conflict of Interests}

Authors declare no conflict of interests.

\section{Authors' Contribution}

Both Hetron Mweemba Munangandu and Øystein Evensen participated in collecting the information leading to preparation of this paper. Both authors read the paper and approved its publication.

\section{Acknowledgments}

Work leading to preparation of this paper was funded by the TARGETFISH, Targeted Disease Prophylaxis in European Fish Farming, EU Grant 311993. The authors are grateful to Dr. TY Kuo for making the PE-VP2-KDEL fusion protein construct (Figure 2) described in Section 3.3 in the paper and Dr. Inderjit Majara for his part in the PE-VP2-KDEL fusion protein verification studies. The authors are also grateful to Dr. Ida Skaar for the illustrative drawing of Figure 2.

\section{References}

[1] G. A. Bishop, S. A. Haxhinasto, L. L. Stunz, and B. S. Hostager, "Antigen-specific B-lymphocyte activation," Critical Reviews in Immunology, vol. 23, no. 3, pp. 149-197, 2003.

[2] R. N. Germain, "MHC-dependent antigen processing and peptide presentation: providing ligands for T lymphocyte activation," Cell, vol. 76, no. 2, pp. 287-299, 1994.

[3] V. Schuette and S. Burgdorf, "The ins-and-outs of endosomal antigens for cross-presentation," Current Opinion in Immunology, vol. 26, no. 1, pp. 63-68, 2014.

[4] E. Segura and J. A. Villadangos, "A modular and combinatorial view of the antigen cross-presentation pathway in dendritic cells," Traffic, vol. 12, no. 12, pp. 1677-1685, 2011.

[5] A. Ciechanover, "Intracellular protein degradation: from a vague idea, through the lysosome and the ubiquitin-proteasome system, and onto human diseases and drug targeting (Nobel Lecture)," Angewandte Chemie - International Edition, vol. 44, no. 37, pp. 5944-5967, 2005.

[6] S. Uebel and R. Tampé, "Specificity of the proteasome and the TAP transporter," Current Opinion in Immunology, vol. 11, no. 2, pp. 203-208, 1999.

[7] J.-O. Koopmann, M. Post, J. J. Neefjes, G. J. Hämmerling, and F. Momburg, "Translocation of long peptides by transporters associated with antigen processing (TAP)," European Journal of Immunology, vol. 26, no. 8, pp. 1720-1728, 1996.

[8] J. O. Koopmann, G. J. Hämmerling, and F. Momburg, "Generation, intracellular transport and loading of peptides associated with MHC class I molecules," Current Opinion in Immunology, vol. 9, no. 1, pp. 80-88, 1997.

[9] E. Pamer and P. Cresswell, "Mechanisms of MHC class Irestricted antigen processing," Annual Review of Immunology, vol. 16, pp. 323-358, 1998. 
[10] N. Mizushima and D. J. Klionsky, "Protein turnover via autophagy: implications for metabolism," Annual Review of Nutrition, vol. 27, pp. 19-40, 2007.

[11] C. Münz, "Antigen processing via autophagy—not only for MHC class II presentation anymore?" Current Opinion in Immunology, vol. 22, no. 1, pp. 89-93, 2010.

[12] G. T. Haugland, A. E. O. Jordal, and H. I. Wergeland, "Characterization of small, mononuclear blood cells from salmon having high phagocytic capacity and ability to differentiate into dendritic like cells," PLoS ONE, vol. 7, no. 11, Article ID e49260, 2012.

[13] D. B. Iliev, H. Thim, L. Lagos, R. Olsen, and J. B. Jørgensen, "Homing of antigen-presenting cells in head kidney and spleen-salmon head kidney hosts diverse APC types," Frontiers in Immunology, vol. 4, article 137, Article ID Article 137, 2013.

[14] G. Lugo-Villarino, K. M. Balla, D. L. Stachura, K. Bañuelos, M. B. F. Werneck, and D. Traver, "Identification of dendritic antigen-presenting cells in the zebrafish," Proceedings of the National Academy of Sciences of the United States of America, vol. 107, no. 36, pp. 15850-15855, 2010.

[15] D. T. Fearon and R. M. Locksley, "The instructive role of innate immunity in the acquired immune response," Science, vol. 272, no. 5258, pp. 50-54, 1996.

[16] T. H. Mogensen, "Pathogen recognition and inflammatory signaling in innate immune defenses," Clinical Microbiology Reviews, vol. 22, no. 2, pp. 240-273, 2009.

[17] S. Akira, S. Uematsu, and O. Takeuchi, "Pathogen recognition and innate immunity," Cell, vol. 124, no. 4, pp. 783-801, 2006.

[18] S. MacKenzie, J. V. Planas, and F. W. Goetz, "LPS-stimulated expression of a tumor necrosis factor-alpha mRNA in primary trout monocytes and in vitro differentiated macrophages," Developmental and Comparative Immunology, vol. 27, no. 5, pp. 393-400, 2003.

[19] J. L. Stafford, P. E. McLauchlan, C. J. Secombes, A. E. Ellis, and M. Belosevic, "Generation of primary monocyte-like cultures from rainbow trout head kidney leukocytes," Developmental and Comparative Immunology, vol. 25, no. 5-6, pp. 447-459, 2001.

[20] F. W. Goetz, D. B. Iliev, L. A. R. McCauley et al., "Analysis of genes isolated from lipopolysaccharide-stimulated rainbow trout (Oncorhynchus mykiss) macrophages," Molecular Immunology, vol. 41, no. 12, pp. 1199-1210, 2004.

[21] D. B. Iliev, C. Q. Liarte, S. MacKenzie, and F. W. Goetz, "Activation of rainbow trout (Oncorhynchus mykiss) mononuclear phagocytes by different pathogen associated molecular pattern (PAMP) bearing agents," Molecular Immunology, vol. 42, no. 10, pp. 1215-1223, 2005.

[22] D. B. Iliev, G. W. Goetz, S. MacKenzie, J. V. Planas, and F. W. Goetz, "Pathogen-associated gene expression profiles in rainbow trout macrophages," Comparative Biochemistry and Physiology Part D: Genomics \& Proteomics, vol. 1, no. 4, pp. 416422, 2006.

[23] E. F. Pettersen, H.-C. Ingerslev, V. Stavang, M. Egenberg, and H. I. Wergeland, "A highly phagocytic cell line TO from Atlantic salmon is CD83 positive and M-CSFR negative, indicating a dendritic-like cell type," Fish \& Shellfish Immunology, vol. 25, no. 6, pp. 809-819, 2008.

[24] H. I. Wergeland and R. A. Jakobsen, "A salmonid cell line (TO) for production of infectious salmon anaemia virus (ISAV)," Diseases of Aquatic Organisms, vol. 44, no. 3, pp. 183-190, 2001.
[25] C. $\mathrm{Xu}, \varnothing$. Evensen, and H. M. Munangandu, “De novo assembly and transcriptome analysis of Atlantic salmon macrophage/dendritic-like TO cells following type I IFN treatment and Salmonid alphavirus subtype-3 infection," BMC Genomics, vol. 16, no. 1, 2015.

[26] E. Bassity and T. G. Clark, "Functional identification of dendritic cells in the teleost model, rainbow trout (Oncorhynchus mykiss)," PLoS ONE, vol. 7, no. 3, Article ID e33196, 2012.

[27] J. O. Sunyer, "Evolutionary and functional relationships of B cells from fish and mammals: insights into their novel roles in phagocytosis and presentation of particulate antigen," Infectious Disorders-Drug Targets, vol. 12, no. 3, pp. 200-212, 2012.

[28] Y. Ohta, D. E. Haliniewski, J. Hansen, and M. F. Flajnik, "Isolation of transporter associated with antigen processing genes, TAP1 and TAP2, from the horned shark Heterodontus francisci," Immunogenetics, vol. 49, no. 11-12, pp. 981-986, 1999.

[29] Y. Ohta, S. J. Powis, W. J. Coadwell et al., "Identification and genetic mapping of Xenopus TAP2 genes," Immunogenetics, vol. 49, no. 3, pp. 171-182, 1999.

[30] J. D. Hansen, P. Strassburger, G. H. Thorgaard, W. P. Young, and L. Du Pasquier, "Expression, linkage, and polymorphism of MHC-related genes in rainbow trout, Oncorhynchus mykiss," Journal of Immunology, vol. 163, no. 2, pp. 774-786, 1999.

[31] U. Grimholt, "Transport-associated proteins in Atlantic salmon (Salmo salar)," Immunogenetics, vol. 46, no. 3, pp. 213-221, 1997.

[32] U. H. von Andrian and T. R. Mempel, "Homing and cellular traffic in lymph nodes," Nature Reviews Immunology, vol. 3, no. 11, pp. 867-878, 2003.

[33] C. M. Press and $\varnothing$. Evensen, "The morphology of the immune system in teleost fishes," Fish and Shellfish Immunology, vol. 9, no. 4, pp. 309-318, 1999.

[34] I. Mulero, M. Pilar Sepulcre, F. J. Roca, J. Meseguer, A. GarcíaAyala, and V. Mulero, "Characterization of macrophages from the bony fish gilthead seabream using an antibody against the macrophage colony-stimulating factor receptor," Developmental and Comparative Immunology, vol. 32, no. 10, pp. 1151-1159, 2008.

[35] M. C. Peleteiro and R. H. Richards, "Phagocytic-cells in the epidermis of rainbow-trout, Salmo-Gairdneri Richardson," Journal of Fish Diseases, vol. 13, no. 3, pp. 225-232, 1990.

[36] B. Fuglem, E. Jirillo, I. Bjerkås et al., "Antigen-sampling cells in the salmonid intestinal epithelium," Developmental and Comparative Immunology, vol. 34, no. 7, pp. 768-774, 2010.

[37] J. H. W. M. Rombout, C. H. J. Lamers, M. H. Helfrich, A. Dekker, and J. J. Taverne-Thiele, "Uptake and transport of intact macromolecules in the intestinal epithelium of carp (Cyprinus carpio L.) and the possible immunological implications," Cell and Tissue Research, vol. 239, no. 3, pp. 519-530, 1985.

[38] A. Alejo and C. Tafalla, "Chemokines in teleost fish species," Developmental and Comparative Immunology, vol. 35, no. 12, pp. 1215-1222, 2011.

[39] K. J. Laing and C. J. Secombes, "Chemokines," Developmental and Comparative Immunology, vol. 28, no. 5, pp. 443-460, 2004.

[40] C. J. Secombes, T. Wang, S. Hong et al., "Cytokines and innate immunity of fish," Developmental and Comparative Immunology, vol. 25, no. 8-9, pp. 713-723, 2001.

[41] C. Tafalla, J. Coll, and C. J. Secombes, "Expression of genes related to the early immune response in rainbow trout (Oncorhynchus mykiss) after viral haemorrhagic septicemia virus (VHSV) infection," Developmental and Comparative Immunology, vol. 29, no. 7, pp. 615-626, 2005. 
[42] C. Doñate, N. Roher, J. C. Balasch et al., "CD83 expression in sea bream macrophages is a marker for the LPS-induced inflammatory response," Fish \& Shellfish Immunology, vol. 23, no. 4, pp. 877-885, 2007.

[43] P. Johansson, Y. Corripio-Miyar, T. Wang, B. Collet, C. J. Secombes, and J. Zou, "Characterisation and expression analysis of the rainbow trout (Oncorhynchus mykiss) homologue of the human dendritic cell marker CD208/lysosomal associated membrane protein 3," Developmental and Comparative Immunology, vol. 37, no. 3-4, pp. 402-413, 2012.

[44] L.-Y. Zhu, A.-F. Lin, T. Shao et al., "B cells in teleost fish act as pivotal initiating APCs in priming adaptive immunity: an evolutionary perspective on the origin of the B-1 cell subset and B7 molecules," The Journal of Immunology, vol. 192, no. 6, pp. 2699-2714, 2014.

[45] B. Abós, R. Castro, G. A. Granja et al., "Early activation of teleost B cells in response to rhabdovirus infection," Journal of Virology, vol. 89, no. 3, pp. 1768-1780, 2015.

[46] A. Pellegrini, N. Guiñazú, M. P. Aoki et al., "Spleen B cells from $\mathrm{BALB} / \mathrm{c}$ are more prone to activation than spleen $\mathrm{B}$ cells from C57BL/6 mice during a secondary immune response to cruzipain," International Immunology, vol. 19, no. 12, pp. 13951402, 2007.

[47] D. Bernard, B. Riteau, J. D. Hansen et al., "Costimulatory receptors in a teleost fish: typical CD28, elusive CTLA4," The Journal of Immunology, vol. 176, no. 7, pp. 4191-4200, 2006.

[48] D. Bernard, J. D. Hansen, L. Du Pasquier, M.-P. Lefranc, A. Benmansour, and P. Boudinot, "Costimulatory receptors in jawed vertebrates: conserved CD28, odd CTLA4 and multiple BTLAs," Developmental and Comparative Immunology, vol. 31, no. 3, pp. 255-271, 2007.

[49] Y.-T. Chang, Y.-H. Kai, S.-C. Chi, and Y.-L. Song, "Cytotoxic $\mathrm{CD} 8 \alpha+$ leucocytes have heterogeneous features in antigen recognition and class I MHC restriction in grouper," Fish \& Shellfish Immunology, vol. 30, no. 6, pp. 1283-1293, 2011.

[50] U. Fischer, K. Utke, M. Ototake, J. M. Dijkstra, and B. Köllner, "Adaptive cell-mediated cytotoxicity against allogeneic targets by CD8-positive lymphocytes of rainbow trout (Oncorhynchus mykiss)," Developmental and Comparative Immunology, vol. 27, no. 4, pp. 323-337, 2003.

[51] H. M. Munang'andu, B. N. Fredriksen, S. Mutoloki, R. A. Dalmo, and $\varnothing$. Evensen, "The kinetics of $\mathrm{CD}^{+}$and $\mathrm{CD}^{+}$ T-cell gene expression correlate with protection in Atlantic salmon (Salmo salar $\mathrm{L}$ ) vaccinated against infectious pancreatic necrosis," Vaccine, vol. 31, no. 15, pp. 1956-1963, 2013.

[52] T. Nakanishi, U. Fischer, J. M. Dijkstra et al., "Cytotoxic T cell function in fish," Developmental and Comparative Immunology, vol. 26, no. 2, pp. 131-139, 2002.

[53] T. Nakanishi, H. Toda, Y. Shibasaki, and T. Somamoto, "Cytotoxic T cells in teleost fish," Developmental and Comparative Immunology, vol. 35, no. 12, pp. 1317-1323, 2011.

[54] T. Somamoto, T. Nakanishi, and N. Okamoto, "Specific cellmediated cytotoxicity against a virus-infected syngeneic cell line in isogeneic ginbuna crucian carp," Developmental and Comparative Immunology, vol. 24, no. 6-7, pp. 633-640, 2000.

[55] E. Andersson and T. Matsunaga, "Complete cDNA sequence of a rainbow trout IgM gene and evolution of vertebrate IgM constant domains," Immunogenetics, vol. 38, no. 4, pp. 243-250, 1993.

[56] I. Hordvik, A. M. Voie, J. Glette, R. Male, and C. Endresen, "Cloning and sequence analysis of two isotypic IgM heavy chain genes from Atlantic salmon, Salmo salar L," European Journal of Immunology, vol. 22, no. 11, pp. 2957-2962, 1992.

[57] I. Hordvik, J. Thevarajan, I. Samdal, N. Bastani, and B. Krossøy, "Molecular cloning and phylogenetic analysis of the Atlantic salmon immunoglobulin D gene," Scandinavian Journal of Immunology, vol. 50, no. 2, pp. 202-210, 1999.

[58] J. D. Hansen, E. D. Landis, and R. B. Phillips, "Discovery of a unique Ig heavy-chain $(\operatorname{Ig} T)$ in rainbow trout: implications for a distinctive B cell developmental pathway in teleost fish," Proceedings of the National Academy of Sciences of the United States of America, vol. 102, no. 19, pp. 6919-6924, 2005.

[59] E. Bromage, F. Ramirez-Gomez, W. Greene et al., "Secretory IgD has an evolutionarily conserved role in respiratory mucosal defense," The Journal of Immunology, vol. 188, 2012.

[60] F. Ramirez-Gomez, W. Greene, K. Rego et al., "Discovery and characterization of secretory $\operatorname{IgD}$ in rainbow trout: secretory IgD is produced through a novel splicing mechanism," Journal of Immunology, vol. 188, no. 3, pp. 1341-1349, 2012.

[61] D. Parra, F. Takizawa, and J. O. Sunyer, "Evolution of B cell immunity," Annual Review of Animal Biosciences, vol. 1, no. 1, pp. 65-97, 2013.

[62] Y.-A. Zhang, I. Salinas, J. Li et al., "IgT, a primitive immunoglobulin class specialized in mucosal immunity," Nature Immunology, vol. 11, no. 9, pp. 827-835, 2010.

[63] Z. Xu, D. Gomez, D. Parra, F. Takizawa, and J. O. Sunyer, "IgT plays a prominent role in gill immune response of rainbow trout," Fish \& Shellfish Immunology, vol. 34, no. 6, 1686 pages, 2013.

[64] J. Banchereau, F. Bazan, D. Blanchard et al., "The CD40 antigen and its ligand," Annual Review of Immunology, vol. 12, pp. 881922, 1994.

[65] L. X. Lagos, D. B. Iliev, R. Helland, M. Rosemblatt, and J. B. Jørgensen, "CD40L-a costimulatory molecule involved in the maturation of antigen presenting cells in Atlantic salmon (Salmo salar L)," Developmental and Comparative Immunology, vol. 38, no. 3, pp. 416-430, 2012.

[66] F. Takizawa, K. Araki, M. Ohtani et al., “Transcription analysis of two Eomesodermin genes in lymphocyte subsets of two teleost species," Fish \& Shellfish Immunology, vol. 36, no. 1, pp. 215-222, 2014.

[67] T. Wang, J. W. Holland, S. A. M. Martin, and C. J. Secombes, "Sequence and expression analysis of two $\mathrm{T}$ helper master transcription factors, T-bet and GATA3, in rainbow trout Oncorhynchus mykiss and analysis of their expression during bacterial and parasitic infection," Fish \& Shellfish Immunology, vol. 29, no. 5, pp. 705-715, 2010.

[68] H. Chi, Z. Zhang, M. Inami, J. Bøgwald, W. Zhan, and R. A. Dalmo, "Molecular characterizations and functional assessments of GATA-3 and its splice variant in Atlantic cod (Gadus morhua L.)," Developmental and Comparative Immunology, vol. 36, no. 3, pp. 491-501, 2012.

[69] J. Kumari, J. Bogwald, and R. A. Dalmo, "Transcription factor GATA-3 in Atlantic salmon (Salmo salar): molecular characterization, promoter activity and expression analysis," Molecular Immunology, vol. 46, no. 15, pp. 3099-3107, 2009.

[70] F. Takizawa, E. O. Koppang, M. Ohtani et al., "Constitutive high expression of interleukin-4/13A and GATA-3 in gill and skin of salmonid fishes suggests that these tissues form Th2-skewed immune environments," Molecular Immunology, vol. 48, no. 1213, pp. 1360-1368, 2011.

[71] L. Du, X. Yang, L. Yang, X. Wang, A. Zhang, and H. Zhou, "Molecular evidence for the involvement of ROR $\alpha$ and ROR $\gamma$ 
in immune response in teleost," Fish \& Shellfish Immunology, vol. 33, no. 2, pp. 418-426, 2012.

[72] M. M. Monte, T. H. Wang, M. M. Costa, N. O. Harun, and C. J. Secombes, "Cloning and expression analysis of two ROR- $\gamma$ homologues (ROR- $\gamma$ al and ROR- $\gamma$ a 2 ) in rainbow trout Oncorhynchus mykiss," Fish \& Shellfish Immunology, vol. 33, no. 2, pp. 365-374, 2012.

[73] A. Rivas-Aravena, S. Guajardo, B. Valenzuela et al., "Ribavirin stimulates the immune response of Atlantic salmon," Veterinary Immunology and Immunopathology, vol. 164, no. 1-2, pp. 93-100, 2015.

[74] T. Wang, P. Diaz-Rosales, M. M. Costa et al., "Functional characterization of a nonmammalian IL-21: rainbow trout Oncorhynchus mykiss IL-21 upregulates the expression of the Th cell signature cytokines IFN- $\gamma$, IL-10, and IL-22," The Journal of Immunology, vol. 186, no. 2, pp. 708-721, 2011.

[75] H. Zhou, T. B. Stuge, N. W. Miller et al., "Heterogeneity of channel catfish CTL with respect to target recognition and cytotoxic mechanisms employed," The Journal of Immunology, vol. 167, no. 3, pp. 1325-1332, 2001.

[76] K. Utke, S. Bergmann, N. Lorenzen, B. Köllner, M. Ototake, and U. Fischer, "Cell-mediated cytotoxicity in rainbow trout, Oncorhynchus mykiss, infected with viral haemorrhagic septicaemia virus," Fish \& Shellfish Immunology, vol. 22, no. 3, pp. 182-196, 2007.

[77] Y. H. Kai, Y. C. Wu, and S. C. Chi, "Immune gene expressions in grouper larvae (Epinephelus coioides) induced by bath and oral vaccinations with inactivated betanodavirus," Fish and Shellfish Immunology, vol. 40, no. 2, pp. 563-569, 2014.

[78] Y.-H. Kai and S.-C. Chi, "Efficacies of inactivated vaccines against betanodavirus in grouper larvae (Epinephelus coioides) by bath immunization," Vaccine, vol. 26, no. 11, pp. 1450-1457, 2008.

[79] H.-C. Ingerslev, A. Rønneseth, E. F. Pettersen, and H. I. Wergeland, "Differential expression of immune genes in Atlantic salmon (Salmo salar L.) challenged intraperitoneally or by cohabitation with IPNV," Scandinavian Journal of Immunology, vol. 69, no. 2, pp. 90-98, 2009.

[80] D. L. Hetland, S. M. Jørgensen, K. Skjødt et al., "In situ localisation of major histocompatibility complex class I and class II and CD8 positive cells in infectious salmon anaemia virus (ISAV)infected Atlantic salmon," Fish \& Shellfish Immunology, vol. 28, no. 1, pp. 30-39, 2010.

[81] H. M. Munang'andu, B. N. Fredriksen, S. Mutoloki, R. A. Dalmo, and $\varnothing$. Evensen, "Antigen dose and humoral immune response correspond with protection for inactivated infectious pancreatic necrosis virus vaccines in Atlantic salmon (Salmo salar L)," Veterinary Research, vol. 44, no. 1, article 7, 2013.

[82] H. M. Munang'andu, A. Sandtrø, S. Mutoloki, B. E. Brudeseth, N. Santi, and Ø. Evensen, "Immunogenicity and cross protective ability of the central VP2 amino acids of infectious pancreatic necrosis virus in Atlantic salmon (Salmo salar L.)," PLoS ONE, vol. 8, no. 1, Article ID e54263, 2013.

[83] K. A. Roberti, J. S. Rohovec, and J. R. Winton, "Vaccination of rainbow trout against infectious hematopoietic necrosis (IHN) by using attenuated mutants selected by neutralizing monoclonal antibodies," Journal of Aquatic Animal Health, vol. 10, no. 4, pp. 328-337, 1998.

[84] M. Adelmann, B. Köllner, S. M. Bergmann et al., "Development of an oral vaccine for immunisation of rainbow trout (Oncorhynchus mykiss) against viral haemorrhagic septicaemia," Vaccine, vol. 26, no. 6, pp. 837-844, 2008.
[85] J. L. Fryer, J. S. Rohovec, G. L. Tebbit, J. S. McMichael, and K. S. Pilcher, "Vaccination for the control of infectious diseases in Pacific salmon," Fish Pathology, vol. 10, no. 2, pp. 155-164, 1976.

[86] G. L. Tebbit, Viruses infecting salmonid fishes from Oregon. A. The occurence and distribution of infectious pancreatic necrosis virus; $B$. The development of an attenuated strain of infectious hematopoietic necrosis virus (IHNV) for the immunization of salmonids [Ph.D. thesis], Oregon State University, Corvallis, Ore, USA, 1976.

[87] J. C. Leong and J. L. Fryer, "Viral vaccines for aquaculture," Annual Review of Fish Diseases, vol. 3, pp. 225-240, 1993.

[88] J. S. Rohovec, J. R. Winton, and J. L. Fryer, "Bacterins and vaccines for the control of infectious diseases of fish," in Proceedings of the Republic of China-United State Cooperative Science Seminar on Fish diseases, NSC Symposium Series no. 3, National Science Council, Beijing, China, 1981.

[89] M. Dorson, J. Castric, and C. Torchy, "Infectious pancreatic necrosis virus of salmonids: biological and antigenic features of a pathogenic strain and of a non-pathogenic variant selected in RTG-2 cells," Journal of Fish Diseases, vol. 1, no. 4, pp. 309-320, 1978.

[90] M. I. Thoulouze, E. Bouguyon, C. Carpentier, and M. Brémont, "ssential role of the NV protein of Novirhabdovirus for pathogenicity in rainbow trout," Journal of Virology, vol. 78, no. 8, pp. 4098-4107, 2004.

[91] A. Romero, A. Figueras, M.-I. Thoulouze, M. Bremont, and B. Novoa, "Recombinant infectious hematopoietic necrosis viruses induce protection for rainbow trout Oncorhynchus mykiss," Diseases of Aquatic Organisms, vol. 80, no. 2, pp. 123135, 2008.

[92] N. Santi, V. N. Vakharia, and Ø. Evensen, "Identification of putative motifs involved in the virulence of infectious pancreatic necrosis virus," Virology, vol. 322, no. 1, pp. 31-40, 2004.

[93] S. Mutoloki, H. Munang'andu, and $\varnothing$. Evensen, "Clinical and subclinical forms of infectious pancreatic necrosis virus infections show specific viral genetic fingerprints that link differences in virulence to immunogenicity," Fish \& Shellfish Immunology, vol. 34, no. 6, p. 1667, 2013.

[94] K. Gadan, A. Sandtrø, I. S. Marjara, N. Santi, H. M. Munang'andu, and $\varnothing$. Evensen, "Stress-induced reversion to virulence of infectious pancreatic necrosis virus in naive fry of Atlantic salmon (Salmo salar L.)," PLoS ONE, vol. 8, no. 2, Article ID e54656, 2013.

[95] P. Boudinot, M. Blanco, P. De Kinkelin, and A. Benmansour, "Combined DNA immunization with the glycoprotein gene of viral hemorrhagic septicemia virus and infectious hematopoietic necrosis virus induces double-specific protective immunity and nonspecific response in rainbow trout," Virology, vol. 249, no. 2, pp. 297-306, 1998.

[96] K. Utke, H. Kock, H. Schuetze et al., "Cell-mediated immune responses in rainbow trout after DNA immunization against the viral hemorrhagic septicemia virus," Developmental and Comparative Immunology, vol. 32, no. 3, pp. 239-252, 2008.

[97] R. Castro, S. Martínez-Alonso, U. Fischer et al., "DNA vaccination against a fish rhabdovirus promotes an early chemokinerelated recruitment of B cells to the muscle," Vaccine, vol. 32, no. 10, pp. 1160-1168, 2014.

[98] S. Corbeil, S. E. Lapatra, E. D. Anderson, and G. Kurath, "Nanogram quantities of a DNA vaccine protect rainbow trout fry against heterologous strains of infectious hematopoietic necrosis virus," Vaccine, vol. 18, no. 25, pp. 2817-2824, 2000. 
[99] D. J. Shedlock and D. B. Weiner, "DNA vaccination: antigen presentation and the induction of immunity," Journal of Leukocyte Biology, vol. 68, no. 6, pp. 793-806, 2000.

[100] F. Fu, Y. Lang, X. Li et al., "Evaluation of the enhancing ability of three adjuvants for DNA vaccination using the porcine circovirus type 2 ORF2 (capsid) gene in mice," Virus Research, vol. 171, no. 1, pp. 247-251, 2013.

[101] N. Jimenez, J. Coll, F. J. Salguero, and C. Tafalla, "Co-injection of interleukin 8 with the glycoprotein gene from viral haemorrhagic septicemia virus (VHSV) modulates the cytokine response in rainbow trout (Oncorhynchus mykiss)," Vaccine, vol. 24, no. 27-28, pp. 5615-5626, 2006.

[102] D. C. Smith, R. A. Spooner, P. D. Watson et al., "Internalized pseudomonas exotoxin A can exploit multiple pathways to reach the endoplasmic reticulum," Traffic, vol. 7, no. 4, pp. 379393, 2006.

[103] H. M. Munang'andu, B. N. Fredriksen, S. Mutoloki et al., "Comparison of vaccine efficacy for different antigen delivery systems for infectious pancreatic necrosis virus vaccines in Atlantic salmon (Salmo salar L.) in a cohabitation challenge model," Vaccine, vol. 30, no. 27, pp. 4007-4016, 2012.

[104] Z. Li-Li, L. Min, G. Jun-Wei, Q. Xin-Yuan, L. Yi-Jing, and L. Di-Qiu, "Expression of infectious pancreatic necrosis virus (IPNV) VP2-VP3 fusion protein in Lactobacillus casei and immunogenicity in rainbow trouts," Vaccine, vol. 30, no. 10, pp. 1823-1829, 2012.

[105] T. Akagi, M. Baba, and M. Akashi, "Biodegradable nanoparticles as vaccine adjuvants and delivery systems: regulation of immune responses by nanoparticle-based vaccine," in Polymers in Nanomedicine, vol. 247 of Advances in Polymer Science, pp. 31-64, Springer, Berlin, Germany, 2012.

[106] M. L. Hans, C. Maxwell, R. S. Ehrlichman et al., "Evaluation of in vitro release and in vivo efficacy of mPEG-PLA-haloperidol conjugate micelle-like structures," Journal of Biomedical Materials Research B: Applied Biomaterials, vol. 83, no. 2, pp. 422-430, 2007.

[107] E. Schlosser, M. Mueller, S. Fischer et al., “TLR ligands and antigen need to be coencapsulated into the same biodegradable microsphere for the generation of potent cytotoxic T lymphocyte responses," Vaccine, vol. 26, no. 13, pp. 1626-1637, 2008.

[108] J. Y. Tian, X. Q. Sun, X. G. Chen, J. Yuc, L. Y. Qu, and L. C. Wang, "The formulation and immunisation of oral poly(DLlactide-co-glycolide) microcapsules containing a plasmid vaccine against lymphocystis disease virus in Japanese flounder (Paralichthys olivaceus)," International Immunopharmacology, vol. 8, no. 6, pp. 900-908, 2008.

[109] J. Y. Tian, X. Q. Sun, and X. G. Chen, "Formation and oral administration of alginate microspheres loaded with pDNA coding for lymphocystis disease virus (LCDV) to Japanese flounder," Fish and Shellfish Immunology, vol. 24, no. 5, pp. 592599, 2008.

[110] J. Tian, J. Yu, and X. Q. Sun, "Chitosan microspheres as candidate plasmid vaccine carrier for oral immunisation of Japanese flounder (Paralichthys olivaceus)," Veterinary Immunology and Immunopathology, vol. 126, no. 3-4, pp. 220-229, 2008.

[111] F.-R. Zheng, X.-Q. Sun, H.-Z. Liu, and J.-X. Zhang, "Study on the distribution and expression of a DNA vaccine against lymphocystis disease virus in Japanese flounder (Paralichthys olivaceus)," Aquaculture, vol. 261, no. 4, pp. 1128-1134, 2006.

[112] S. Rajeshkumar, C. Venkatesan, M. Sarathi et al., "Oral delivery of DNA construct using chitosan nanoparticles to protect the shrimp from white spot syndrome virus (WSSV)," Fish and Shellfish Immunology, vol. 26, no. 3, pp. 429-437, 2009.

[113] G. Sahay, D. Y. Alakhova, and A. V. Kabanov, "Endocytosis of nanomedicines," Journal of Controlled Release, vol. 145, no. 3, pp. 182-195, 2010.

[114] S. M. Standley, Y. J. Kwon, N. Murthy et al., "Acid-degradable particles for protein-based vaccines: Enhanced survival rate for tumor-challenged mice using ovalbumin model," Bioconjugate Chemistry, vol. 15, no. 6, pp. 1281-1288, 2004.

[115] R. A. Jones, C. Y. Cheung, F. E. Black et al., "Poly(2-alkylacrylic acid) polymers deliver molecules to the cytosol by $\mathrm{pH}$-sensitive disruption of endosomal vesicles," Biochemical Journal, vol. 372, no. 1, pp. 65-75, 2003.

[116] N. Murthy, J. R. Robichaud, D. A. Tirrell, P. S. Stayton, and A. S. Hoffman, "The design and synthesis of polymers for eukaryotic membrane disruption," Journal of Controlled Release, vol. 61, no. 1-2, pp. 137-143, 1999.

[117] T. Yoshikawa, N. Okada, A. Oda et al., "Development of amphiphilic $\gamma$-PGA-nanoparticle based tumor vaccine: potential of the nanoparticulate cytosolic protein delivery carrier," Biochemical and Biophysical Research Communications, vol. 366, no. 2, pp. 408-413, 2008.

[118] C. Kusonwiriyawong, P. van de Wetering, J. A. Hubbell, H. P. Merkle, and E. Walter, "Evaluation of pH-dependent membrane-disruptive properties of poly(acrylic acid) derived polymers," European Journal of Pharmaceutics and Biopharmaceutics, vol. 56, no. 2, pp. 237-246, 2003.

[119] S. Foster, C. L. Duvall, E. F. Crownover, A. S. Hoffman, and P. S. Stayton, "Intracellular delivery of a protein antigen with an endosomal-releasing polymer enhances CD8 T-cell production and prophylactic vaccine efficacy," Bioconjugate Chemistry, vol. 21, no. 12, pp. 2205-2212, 2010.

[120] C. B. He, Y. P. Hu, L. C. Yin, C. Tang, and C. H. Yin, "Effects of particle size and surface charge on cellular uptake and biodistribution of polymeric nanoparticles," Biomaterials, vol. 31, no. 13, pp. 3657-3666, 2010.

[121] L. Thiele, B. Rothen-Rutishauser, S. Jilek, H. WunderliAllenspach, H. P. Merkle, and E. Walter, "Evaluation of particle uptake in human blood monocyte-derived cells in vitro. Does phagocytosis activity of dendritic cells measure up with macrophages?" Journal of Controlled Release, vol. 76, no. 1-2, pp. 59-71, 2001.

[122] S. Burgdorf and C. Kurts, "Endocytosis mechanisms and the cell biology of antigen presentation," Current Opinion in Immunology, vol. 20, no. 1, pp. 89-95, 2008.

[123] S. A. Agnihotri, N. N. Mallikarjuna, and T. M. Aminabhavi, "Recent advances on chitosan-based micro- and nanoparticles in drug delivery," Journal of Controlled Release, vol. 100, no. 1, pp. 5-28, 2004.

[124] I. Gutierro, R. M. Hernández, M. Igartua, A. R. Gascón, and J. L. Pedraz, "Size dependent immune response after subcutaneous, oral and intranasal administration of BSA loaded nanospheres," Vaccine, vol. 21, no. 1-2, pp. 67-77, 2002.

[125] T. Fehr, D. Skrastina, P. Pumpens, and R. M. Zinkernagel, "T cell-independent type I antibody response against B cell epitopes expressed repetitively on recombinant virus particles," Proceedings of the National Academy of Sciences of the United States of America, vol. 95, no. 16, pp. 9477-9481, 1998.

[126] A. Ruyra, M. Cano-Sarabia, S. A. MacKenzie, D. Maspoch, and N. Roher, "A novel liposome based nanocarrier loaded with an LPS-dsRNA cocktail for fish innate immune system stimulation," PLoS ONE, vol. 8, no. 10, Article ID e76338, 2013. 
[127] B. N. Fredriksen and J. Grip, "PLGA/PLA micro- and nanoparticle formulations serve as antigen depots and induce elevated humoral responses after immunization of Atlantic salmon (Salmo salar L.)," Vaccine, vol. 30, no. 3, pp. 656-667, 2012.

[128] S. Broos, K. Lundberg, T. Akagi et al., "Immunomodulatory nanoparticles as adjuvants and allergen-delivery system to human dendritic cells: implications for specific immunotherapy," Vaccine, vol. 28, no. 31, pp. 5075-5085, 2010.

[129] M. Diwan, P. Elamanchili, H. Lane, A. Gainer, and J. Samuel, "Biodegradable nanoparticle mediated antigen delivery to human cord blood derived dendritic cells for induction of primary T cell responses," Journal of Drug Targeting, vol. 11, no. 8-10, pp. 495-507, 2003.

[130] Y. K. Katare, T. Muthukumaran, and A. K. Panda, "Influence of particle size, antigen load, dose and additional adjuvant on the immune response from antigen loaded PLA microparticles," International Journal of Pharmaceutics, vol. 301, no. 1-2, pp. 149160, 2005.

[131] J. Samuel, P. Elamanchili, C. Chong et al., "Biodegradable nanoparticles for targeted delivery of therapeutic vaccines to dendritic cells," The FASEB Journal, vol. 17, no. 7, p. C332, 2003.

[132] Ø. Haugland, J. Torgersen, M. Syed, and Ø. Evensen, "Expression profiles of inflammatory and immune-related genes in Atlantic salmon (Salmo salar L.) at early time post vaccination," Vaccine, vol. 23, no. 48-49, pp. 5488-5499, 2005.

[133] H. M. Munang'andu, S. Mutoloki, and $\varnothing$. Evensen, "Acquired immunity and vaccination against infectious pancreatic necrosis virus of salmon," Developmental \& Comparative Immunology, vol. 43, no. 2, pp. 184-196, 2014.

[134] H. M. Munang'andu, S. Mutoloki, and O. Evensen, "Nonreplicating vaccines," in Fish Vaccination, chapter 3, p. 22, Wiley, 2014.

[135] I. Salinas, Y. A. Zhang, and J. O. Sunyer, "Mucosal immunoglobulins and B cells of teleost fish," Developmental and Comparative Immunology, vol. 35, no. 12, pp. 1346-1365, 2011.

[136] A. Estepa and J. M. Coll, "Enhancement of fish mortality by rhabdovirus infection after immunization with a viral nucleoprotein peptide," Viral Immunology, vol. 6, no. 4, pp. 237-243, 1993.

[137] B. Noonan, P. J. Enzmann, and T. J. Trust, "Recombinant infectious hematopoietic necrosis virus and viral hemorrhagic septicemia virus glycoprotein epitopes expressed in Aeromonas salmonicida induce protective immunity in rainbow trout (Oncorhynchus mykiss)," Applied and Environmental Microbiology, vol. 61, no. 10, pp. 3586-3591, 1995.

[138] L. A. Oberg, J. Wirkkula, D. Mourich, and J. C. Leong, "Bacterially expressed nucleoprotein of infectious hematopoietic necrosis virus augments protective immunity induced by the glycoprotein vaccine in fish," Journal of Virology, vol. 65, no. 8, pp. 4486-4489, 1991.

[139] F. C. T. Allnutt, R. M. Bowers, C. G. Rowe, V. N. Vakharia, S. E. LaPatra, and A. K. Dhar, "Antigenicity of infectious pancreatic necrosis virus VP2 subviral particles expressed in yeast," Vaccine, vol. 25, no. 26, pp. 4880-4888, 2007.

[140] A. B. Mikalsen, J. Torgersen, P. Aleström, A.-L. Hellemann, E.O. Koppang, and E. Rimstad, "Protection of Atlantic salmon, Salmo salar L, against infectious pancreatic necrosis after DNA vaccination," Diseases of Aquatic Organisms, vol. 60, no. 1, pp. 11-20, 2004.

[141] R. B. Shivappa, P. E. McAllister, G. H. Edwards, N. Santi, Ø. Evensen, and V. N. Vakharia, "Development of a subunit vaccine for infectious pancreatic necrosis virus using a baculovirus insect/larvae system," Developments in Biologicals, vol. 121, pp. 165-174, 2005.

[142] F. Lecocq-Xhonneux, M. Thiry, I. Dheur et al., "A recombinant viral haemorrhagic septicaemia virus glycoprotein expressed in insect cells induces protective immunity in rainbow trout," Journal of General Virology, vol. 75, no. 7, pp. 1579-1587, 1994.

[143] A. C. Moore and C. L. Hutchings, "Combination vaccines: synergistic simultaneous induction of antibody and T-cell immunity," Expert Review of Vaccines, vol. 6, no. 1, pp. 111-121, 2007.

[144] A.-C. Øvergård, S. Patel, O. J. Nøstbakken, and A. H. Nerland, "Atlantic halibut (Hippoglossus hippoglossus L.) T-cell and cytokine response after vaccination and challenge with nodavirus," Vaccine, vol. 31, no. 19, pp. 2395-2402, 2013.

[145] A.-C. Øvergård, A. H. Nerland, I. U. Fiksdal, and S. Patel, "Atlantic halibut experimentally infected with nodavirus shows increased levels of T-cell marker and IFN $\gamma$ transcripts," Developmental \& Comparative Immunology, vol. 37, no. 1, pp. 139-150, 2012.

[146] W. Liu, C.-H. Hsu, C.-Y. Chang, H.-H. Chen, and C.-S. Lin, "Immune response against grouper nervous necrosis virus by vaccination of virus-like particles," Vaccine, vol. 24, no. 37-39, pp. 6282-6287, 2006.

[147] L. Tang, C.-S. Lin, N. K. Krishna, M. Yeager, A. Schneemann, and J. E. Johnson, "Virus-like particles of a fish nodavirus display a capsid subunit domain organization different from that of insect nodaviruses," Journal of Virology, vol. 76, no. 12, pp. 6370-6375, 2002.

[148] C.-S. Lin, M.-W. Lu, L. Tang et al., "Characterization of viruslike particles assembled in a recombinant baculovirus system expressing the capsid protein of a fish nodavirus," Virology, vol. 290, no. 1, pp. 50-58, 2001.

[149] Q. Fang, E. K. Seng, Q. Q. Ding, and L. L. Zhang, "Characterization of infectious particles of grass carp reovirus by treatment with proteases," Archives of Virology, vol. 153, no. 4, pp. 675-682, 2008.

[150] A. K. Dhar, R. M. Bowers, C. G. Rowe, and F. C. T. Allnutt, "Expression of a foreign epitope on infectious pancreatic necrosis virus VP2 capsid protein subviral particle (SVP) and immunogenicity in rainbow trout," Antiviral Research, vol. 85, no. 3, pp. 525-531, 2010.

[151] A. Rivas-Aravena, M. C.-S. Martin, J. Galaz et al., "Evaluation of the immune response against immature viral particles of infectious pancreatic necrosis virus (IPNV): a new model to develop an attenuated vaccine," Vaccine, vol. 30, no. 34, pp. 51105117, 2012.

[152] M. W. Lu and C.-S. Lin, "Involvement of the terminus of grouper betanodavirus capsid protein in virus-like particle assembly," Archives of Virology, vol. 148, no. 2, pp. 345-355, 2003.

[153] Y.-X. Lai, B.-L. Jin, Y. Xu et al., "Immune responses of orangespotted grouper, Epinephelus coioides, against virus-like particles of betanodavirus produced in Escherichia coli," Veterinary Immunology and Immunopathology, vol. 157, no. 1-2, pp. 87-96, 2014.

[154] R. A. Goldsby, T. Kindt, J. Kiby, and B. Osborne, Immunology, W.H. Freeman, 5th edition, 2003.

[155] M. O. V. Osinubi, X. Wu, R. Franka et al., "Enhancing comparative rabies DNA vaccine effectiveness through glycoprotein gene modifications," Vaccine, vol. 27, no. 51, pp. 7214-7218, 2009.

[156] N. B. Ray, L. C. Ewalt, and D. L. Lodmell, "Nanogram quantities of plasmid DNA encoding the rabies virus glycoprotein protect 
mice against lethal rabies virus infection," Vaccine, vol. 15, no. 8 , pp. 892-895, 1997.

[157] C. Xu, S. Mutoloki, and $\varnothing$. Evensen, "Superior protection conferred by inactivated whole virus vaccine over subunit and DNA vaccines against salmonid alphavirus infection in Atlantic salmon (Salmo salar L.)," Vaccine, vol. 30, no. 26, pp. 3918-3928, 2012.

[158] M. Howarth and T. Elliott, "The processing of antigens delivered as DNA vaccines," Immunological Reviews, vol. 199, pp. 27-39, 2004.

[159] T. Shao, L.-Y. Zhu, L. Nie et al., "Characterization of surface phenotypic molecules of teleost dendritic cells," Developmental \& Comparative Immunology, vol. 49, no. 1, pp. 38-43, Mar 2015.

[160] M.-F. Li, Y.-X. Li, and L. Sun, "CD83 is required for the induction of protective immunity by a DNA vaccine in a teleost model," Developmental \& Comparative Immunology, vol. 51, no. 1, pp. 141-147, 2015.

[161] J. Wiik-Nielsen, M. Løvoll, C. Fritsvold et al., "Characterization of myocardial lesions associated with cardiomyopathy syndrome in atlantic salmon, Salmo salar L., using laser capture microdissection," Journal of Fish Diseases, vol. 35, no. 12, pp. 907-916, 2012.

[162] A.-F. Lin, L.-X. Xiang, Q.-L. Wang, W.-R. Dong, Y.-F. Gong, and J.-Z. Shao, "The DC-SIGN of zebrafish: insights into the existence of a CD209 homologue in a lower vertebrate and its involvement in adaptive immunity," The Journal of Immunology, vol. 183, no. 11, pp. 7398-7410, 2009.

[163] R. D. Pinto, E. Randelli, F. Buonocore, P. J. B. Pereira, and N. M. S. dos Santos, "Molecular cloning and characterization of sea bass (Dicentrarchus labrax, L.) MHC class I heavy chain and $\beta 2$ microglobulin," Developmental and Comparative Immunology, vol. 39, no. 3, pp. 234-254, 2013.

[164] Z. Y. Xu, P. Nie, M. X. Chang, and B. J. Sun, "Cloning, characterization and expression analysis of SIMP (source of immunodominant MHC-associated peptides) in grass carp Ctenopharyngodon idella," Fish \& Shellfish Immunology, vol. 24, no. 6, pp. 701-714, 2008.

[165] M. A. Noakes, T. Reimer, and R. B. Phillips, "Genotypic characterization of an MHC class II locus in lake trout (Salvelinus namaycush) from Lake Superior by single-stranded conformational polymorphism analysis and reference strand-mediated conformational analysis," Marine Biotechnology, vol. 5, no. 3, pp. 270-278, 2003.

[166] Y. Liu, L. Moore, E. O. Koppang, and I. Hordvik, "Characterization of the $\mathrm{CD} 3 \zeta, \mathrm{CD} 3 \gamma \delta$ and $\mathrm{CD} 3 \varepsilon$ subunits of the $\mathrm{T}$ cell receptor complex in Atlantic salmon," Developmental \& Comparative Immunology, vol. 32, no. 1, pp. 26-35, 2008.

[167] K. J. Laing and J. D. Hansen, "Fish T cells: recent advances through genomics," Developmental and Comparative Immunology, vol. 35, no. 12, pp. 1282-1295, 2011.

[168] P. Ronza, R. Bermúdez, A. P. Losada, A. Robles, and M. I. Quiroga, "Mucosal CD3E+ cell proliferation and gut epithelial apoptosis: implications in rainbow trout gastroenteritis (RTGE)," Journal of Fish Diseases, vol. 34, no. 6, pp. 433-443, 2011.

[169] K. Maisey, D. Toro-Ascuy, R. Montero, F. E. Reyes-López, and M. Imarai, "Identification of CD $3 \varepsilon, \mathrm{CD} 4, \mathrm{CD} 8 \beta$ splice variants of Atlantic salmon," Fish \& Shellfish Immunology, vol. 31, no. 6, pp. 815-822, 2011.

[170] S. Partula, A. De Guerra, J. S. Fellah, and J. Charlemagne, "Structure and diversity of the TCR $\alpha$-chain in a teleost fish," The Journal of Immunology, vol. 157, no. 1, pp. 207-212, 1996.
[171] B. H. Nam, I. Hirono, and T. Aoki, "The four TCR genes of teleost fish: The cDNA and genomic DNA analysis of Japanese flounder (Paralichthys olivaceus) TCR alpha-, beta-, gamma-, and delta-chains," Journal of Immunology, vol. 170, no. 6, pp. 3081-3090, 2003.

[172] C.-I. Park, J. Y. Hwang, I. Hirono, and T. Aoki, "Characterization and expression of a CD40 homolog gene in Japanese flounder Paralichthys olivaceus," Immunogenetics, vol. 57, no. 9, pp. 682689, 2005.

[173] F. Takizawa, J. M. Dijkstra, P. Kotterba et al., "The expression of CD8 $\alpha$ discriminates distinct T cell subsets in teleost fish," Developmental and Comparative Immunology, vol. 35, no. 7, pp. 752-763, 2011.

[174] I. Hordvik, "Immunoglobulin isotypes in Atlantic salmon, Salmo Salar," Biomolecules, vol. 5, no. 1, pp. 166-177, 2015.

[175] E. Bromage, P. Kataria, and F. Ramirez-Gomez, "The structure of rainbow trout IgM influences antibody-mediated phagocytosis of bacteria," The Journal of Immunology, vol. 188, 2012.

[176] Y.-L. Hu, L.-X. Xiang, and J.-Z. Shao, "Identification and characterization of a novel immunoglobulin $\mathrm{Z}$ isotype in zebrafish: implications for a distinct B cell receptor in lower vertebrates," Molecular Immunology, vol. 47, no. 4, pp. 738-746, 2010.

[177] A. Perelberg, A. Ronen, M. Hutoran, Y. Smith, and M. Kotler, "Protection of cultured Cyprinus carpio against a lethal viral disease by an attenuated virus vaccine," Vaccine, vol. 23, no. 26, pp. 3396-3403, 2005.

[178] P. de Kinkelin, M. Bearzotti-Le Berre, and J. Bernard, "Viral hemorrhagic septicemia of rainbow trout: selection of a thermoresistant virus variant and comparison of polypeptide synthesis with the wild-type virus strain," Journal of Virology, vol. 36, no. 3, pp. 652-658, 1980.

[179] W. S. Kim, C. S. Kim, J. K. Cho, J. I. Myung, and M. J. Oh, "Disease control efficacy of synthetic double-stranded RNA Poly(I:C) administration for viral nervous necrosis (VNN) in sevenband grouper (Epinephelus septemfasciatus)," Aquaculture, vol. 364-365, pp. 259-262, 2012.

[180] P.-J. Enzmann, D. Fichtner, H. Schütze, and G. Walliser, "Development of vaccines against VHS and IHN: oral application, molecular marker and discrimination of vaccinated fish from infected populations," Journal of Applied Ichthyology, vol. 14, no. 3-4, pp. 179-183, 1998.

[181] B. Novoa, A. Romero, V. Mulero, I. Rodríguez, I. Fernández, and A. Figueras, "Zebrafish (Danio rerio) as a model for the study of vaccination against viral haemorrhagic septicemia virus (VHSV)," Vaccine, vol. 24, no. 31-32, pp. 5806-5816, 2006.

[182] C. H. Kim, J. R. Winton, and J. C. Leong, "Neutralizationresistant variants of infectious hematopoietic necrosis virus have altered virulence and tissue tropism," Journal of Virology, vol. 68, no. 12, pp. 8447-8453, 1994.

[183] S. S. Ristow, S. E. LaPatra, R. Dixon et al., "Responses of cloned rainbow trout Oncorhynchus mykiss to an attenuated strain of infectious hematopoietic necrosis virus," Diseases of Aquatic Organisms, vol. 42, no. 3, pp. 163-172, 2000.

[184] S.-Y. Oh and T. Nishizawa, "Optimizing the quantitative detection of red seabream iridovirus (RSIV) genome from splenic tissues of rock bream Oplegnathus fasciatus using a qPCR Assay," Fish Pathology, vol. 48, no. 1, pp. 21-24, 2013.

[185] C. M. A. Caipang, T. Takano, I. Hirono, and T. Aoki, "Genetic vaccines protect red seabream, Pagrus major, upon challenge with red seabream iridovirus (RSIV)," Fish \& Shellfish Immunology, vol. 21, no. 2, pp. 130-138, 2006. 
[186] K. E. Nusbaum, B. F. Smith, P. DeInnocentes, and R. C. Bird, "Protective immunity induced by DNA vaccination of channel catfish with early and late transcripts of the channel catfish herpesvirus (IHV-1)," Veterinary Immunology and Immunopathology, vol. 84, no. 3-4, pp. 151-168, 2002.

[187] J. C. Leong, E. Anderson, L. M. Bootland et al., "Fish vaccine antigens produced or delivered by recombinant DNA technologies," Fish Vaccinology, vol. 90, pp. 267-277, 1997.

[188] J. R. Winton, "Immunization with viral antigens: infectious haematopoietic necrosis," Fish Vaccinology, vol. 90, pp. 211-220, 1997.

[189] E. J. Emmenegger and G. Kurath, "DNA vaccine protects ornamental koi (Cyprinus carpio koi) against North American spring viremia of carp virus," Vaccine, vol. 26, no. 50, pp. 6415$6421,2008$.

[190] T. Kanellos, I. D. Sylvester, F. D’Mello et al., “DNA vaccination can protect Cyprinus Carpio against spring viraemia of carp virus," Vaccine, vol. 24, no. 23, pp. 4927-4933, 2006.

[191] T. Takano, A. Iwahori, I. Hirono, and T. Aoki, "Development of a DNA vaccine against hirame rhabdovirus and analysis of the expression of immune-related genes after vaccination," Fish \& Shellfish Immunology, vol. 17, no. 4, pp. 367-374, 2004.

[192] A. B. Mikalsen, H. Sindre, J. Torgersen, and E. Rimstad, "Protective effects of a DNA vaccine expressing the infectious salmon anemia virus hemagglutinin-esterase in Atlantic salmon," Vaccine, vol. 23, no. 41, pp. 4895-4905, 2005.

[193] I. Sommerset, E. Lorenzen, N. Lorenzen, H. Bleie, and A. H. Nerland, "A DNA vaccine directed against a rainbow trout rhabdovirus induces early protection against a nodavirus challenge in turbot," Vaccine, vol. 21, no. 32, pp. 4661-4667, 2003.

[194] J. Y. Tian and J. Yu, "Corrigendum to 'poly (lactic-co-glycolic acid) nanoparticles as candidate DNA vaccine carrier for oral immunization of Japanese flounder (Paralichthys olivaceus) against lymphocystis disease virus' Fish Shellfish Immun. 30 (2011) 109-117," Fish \& Shellfish Immunology, vol. 31, no. 2, p. 364, 2011.

[195] M. Adomako, S. St-Hilaire, Y. Zheng et al., "Oral DNA vaccination of rainbow trout, Oncorhynchus mykiss (Walbaum), against infectious haematopoietic necrosis virus using PLGA [Poly(D,L-Lactic-Co-Glycolic Acid)] nanoparticles," Journal of Fish Diseases, vol. 35, no. 3, pp. 203-214, 2012.

[196] S. Vimal, S. Abdul Majeed, G. Taju et al., "Chitosan tripolyphosphate (CS/TPP) nanoparticles: preparation, characterization and application for gene delivery in shrimp," Acta Tropica, vol. 128, no. 3, pp. 486-493, 2013.

[197] P. de Kinkelin, M. Béarzotti, J. Castric, P. Nougayrède, F. LecocqXhonneux, and M. Thiry, "Eighteen years of vaccination against viral haemorrhagic septicaemia in France," Veterinary Research, vol. 26, no. 5-6, pp. 379-387, 1995.

[198] E. Anderson, S. Clouthier, W. Shewmaker, A. Weighall, and S. LaPatra, "Inactivated infectious haematopoietic necrosis virus (IHNV) vaccines," Journal of Fish Diseases, vol. 31, no. 10, pp. 729-745, 2008.

[199] J. Tesarcík, B. Macura, L. Dedek, L. Valicek, and B. Smíd, "Isolation and electron microscopy of a rhabdovirus from the acute form of infectious dropsy of carp (spring viraemia of carp)," Zentralblatt für Veterinärmedizin Reihe B, vol. 24, no. 4, pp. 340-343, 1977.

[200] M. V. López-Dóriga, D. A. Smail, R. J. Smith et al., "Isolation of salmon pancreas disease virus (SPDV) in cell culture and its ability to protect against infection by the 'wild-type' agent," Fish \& Shellfish Immunology, vol. 11, no. 6, pp. 505-522, 2001.
[201] C. M. A. Caipang, I. Hirono, and T. Aoki, "Immunogenicity, retention and protective effects of the protein derivatives of formalin-inactivated red seabream iridovirus (RSIV) vaccine in red seabream, Pagrus major," Fish \& Shellfish Immunology, vol. 20, no. 4, pp. 597-609, 2006.

[202] Z. L. Ou-Yang, P. R. Wang, X. H. Huang et al., "Immunogenicity and protective effects of inactivated Singapore grouper iridovirus (SGIV) vaccines in orange-spotted grouper, Epinephelus coioides," Developmental and Comparative Immunology, vol. 38, no. 2, pp. 254-261, 2012.

[203] P. Dixon, "Immunization with viral antigens: viral diseases of carp and catfish," Fish Vaccinology, vol. 90, pp. 221-232, 1997.

[204] S. Yasumoto, Y. Kuzuya, M. Yasuda, T. Yoshimura, and T. Miyazaki, "Oral immunization of common carp with a liposome vaccine fusing koi herpesvirus antigen," Fish Pathology, vol. 41, no. 4, pp. 141-145, 2006.

[205] R. Pakingking Jr., N. B. Bautista, E. G. de Jesus-Ayson, and O. Reyes, "Protective immunity against viral nervous necrosis (VNN) in brown-marbled grouper (Epinephelus fuscogutattus) following vaccination with inactivated betanodavirus," Fish \& Shellfish Immunology, vol. 28, no. 4, pp. 525-533, 2010.

[206] R. Pakingking Jr., R. Seron, L. Dela Peña, K. Mori, H. Yamashita, and T. Nakai, "Immune responses of Asian sea bass, Lates calcarifer Bloch, against an inactivated betanodavirus vaccine," Journal of Fish Diseases, vol. 32, no. 5, pp. 457-463, 2009.

[207] A. Lauscher, B. Krossøy, P. Frost et al., "Immune responses in Atlantic salmon (Salmo salar) following protective vaccination against Infectious salmon anemia (ISA) and subsequent ISA virus infection," Vaccine, vol. 29, no. 37, pp. 6392-6401, 2011.

[208] L. Min, Z. Li-Li, G. Jun-Wei, Q. Xin-Yuan, L. Yi-Jing, and L. Di-Qiu, "Immunogenicity of Lactobacillus-expressing VP2 and VP3 of the infectious pancreatic necrosis virus (IPNV) in rainbow trout," Fish and Shellfish Immunology, vol. 32, no. 1, pp. 196-203, 2012.

[209] B. M. McKenna, R. M. Fitzpatrick, K. V. Phenix, D. Todd, L. M. Vaughan, and G. J. Atkins, "Formation of infectious pancreatic necrosis virus-like particles following expression of segment a by recombinant semliki forest virus," Marine Biotechnology, vol. 3, no. 2, pp. 103-110, 2001.

[210] P. de Kinkelin, "Vaccination in fish," Veterinary Research, vol. 26, no. 3, pp. 205-206, 1995.

[211] A. Estepa, M. Thiry, and J. M. Coll, "Recombinant protein fragments from haemorrhagic septicaemia rhabdovirus stimulate trout leukocyte anamnestic responses in vitro," Journal of General Virology, vol. 75, no. 6, pp. 1329-1338, 1994.

[212] S. H. Choi, M. S. Kim, and K. H. Kim, "Immunization of olive flounder (Paralichthys olivaceus) with an auxotrophic Edwardsiella tarda mutant harboring the VHSV DNA vaccine," Fish \& Shellfish Immunology, vol. 33, no. 3, pp. 569-574, 2012.

[213] B. Simon, J. Nomellini, P. Chiou et al., "Recombinant vaccines against infectious hematopoietic necrosis virus: production by the Caulobacter crescentus S-layer protein secretion system and evaluation in laboratory trials," Diseases of Aquatic Organisms, vol. 44, no. 1, pp. 17-27, 2001.

[214] K. D. Cain, S. E. LaPatra, B. Shewmaker, J. Jones, K. M. Byrne, and S. S. Ristow, "Immunogenicity of a recombinant infectious hematopoietic necrosis virus glycoprotein produced in insect cells," Diseases of Aquatic Organisms, vol. 36, no. 1, pp. 67-72, 1999.

[215] Y. Y. Tian, X. Ye, L. L. Zhang, G. C. Deng, and Y. Q. Bai, "Development of a novel candidate subunit vaccine against 
Grass carp reovirus Guangdong strain (GCRV-GD108)," Fish \& Shellfish Immunology, vol. 35, no. 2, pp. 351-356, 2013.

[216] L. Shao, X. Sun, and Q. Fang, "Antibodies against outer-capsid proteins of grass carp reovirus expressed in E. coli are capable of neutralizing viral infectivity," Virology Journal, vol. 8, article 347, 2011.

[217] I. Sommerset, R. Skern, E. Biering et al., "Protection against Atlantic halibut nodavirus in turbot is induced by recombinant capsid protein vaccination but not following DNA vaccination," Fish and Shellfish Immunology, vol. 18, no. 1, pp. 13-29, 2005.

[218] Y. R. Choi, H. J. Kim, J. Y. Lee, H. A. Kang, and H.-J. Kim, "Chromatographically-purified capsid proteins of red-spotted grouper nervous necrosis virus expressed in Saccharomyces cerevisiae form virus-like particles," Protein Expression and Purification, vol. 89, no. 2, pp. 162-168, 2013.

[219] S. Martinez-Alonso, V. N. Vakharia, S. R. Saint-Jean, S. PérezPrieto, and C. Tafalla, "Immune responses elicited in rainbow trout through the administration of infectious pancreatic necrosis virus-like particles," Developmental and Comparative Immunology, vol. 36, no. 2, pp. 378-384, 2012.

[220] Q. Fang, S. Shah, Y. Liang, and Z. H. Zhou, "3D reconstruction and capsid protein characterization of grass carp reovirus," Science in China, Series C: Life Sciences, vol. 48, no. 6, pp. 593600, 2005.

[221] R. Thiéry, J. Cozien, J. Cabon, F. Lamour, M. Baud, and A. Schneemann, "Induction of a protective immune response against viral nervous necrosis in the European sea bass Dicentrarchus labrax by using betanodavirus virus-like particles," Journal of Virology, vol. 80, no. 20, pp. 10201-10207, 2006. 


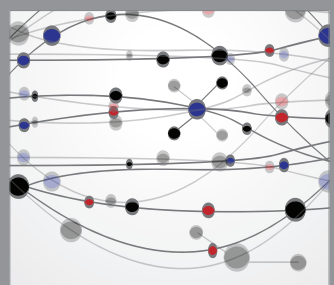

The Scientific World Journal
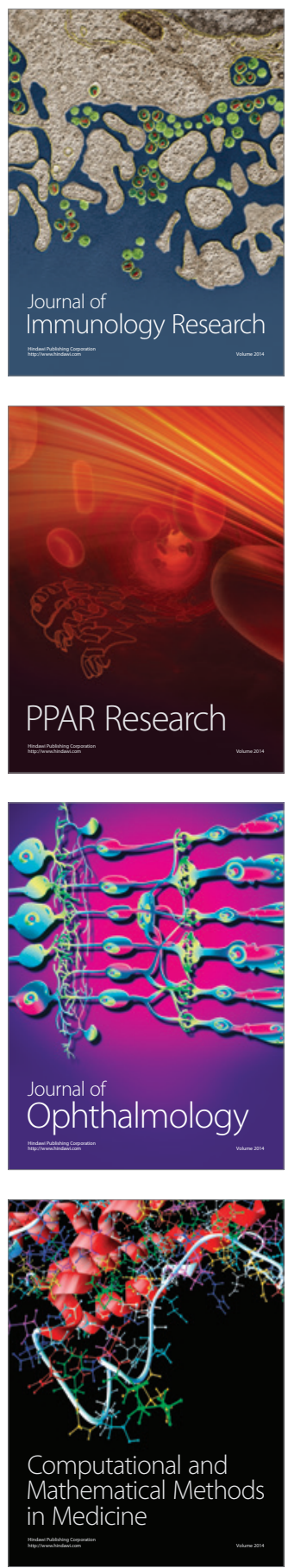

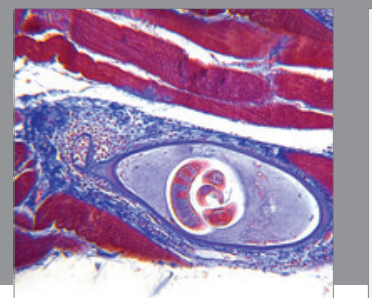

Gastroenterology

Research and Practice
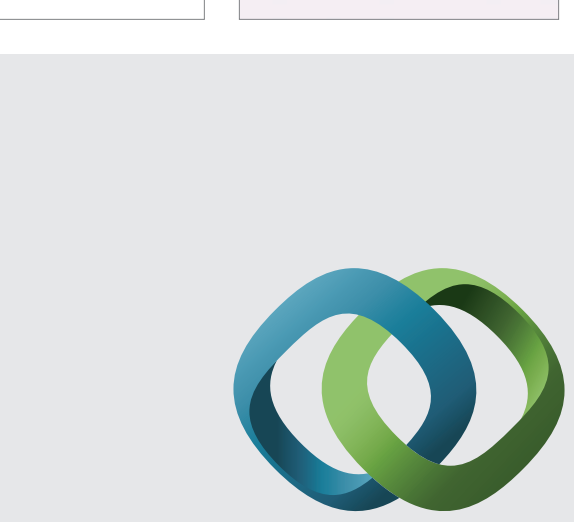

\section{Hindawi}

Submit your manuscripts at

http://www.hindawi.com
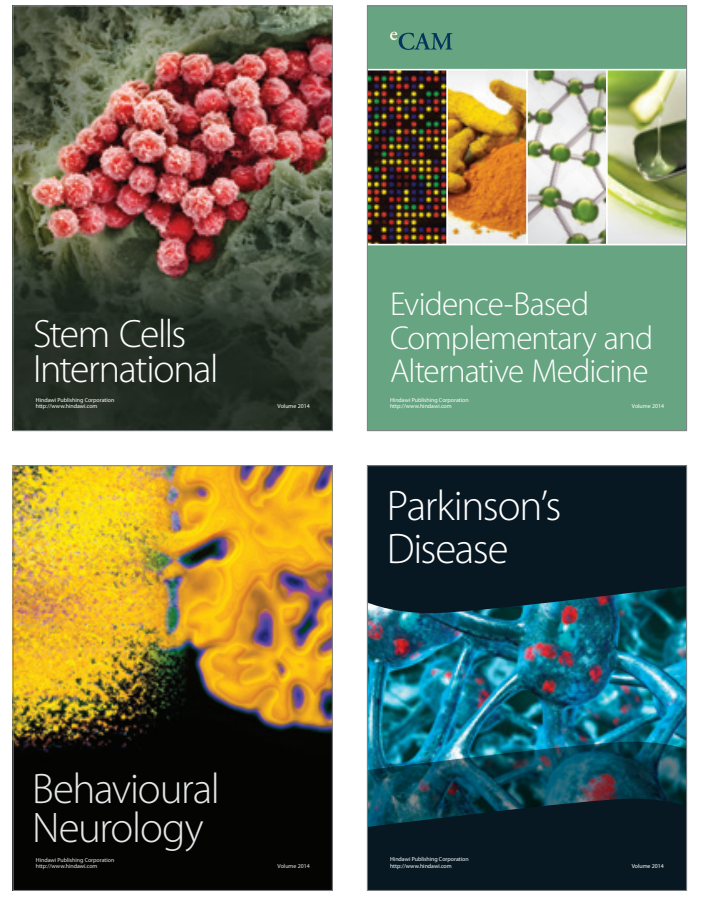
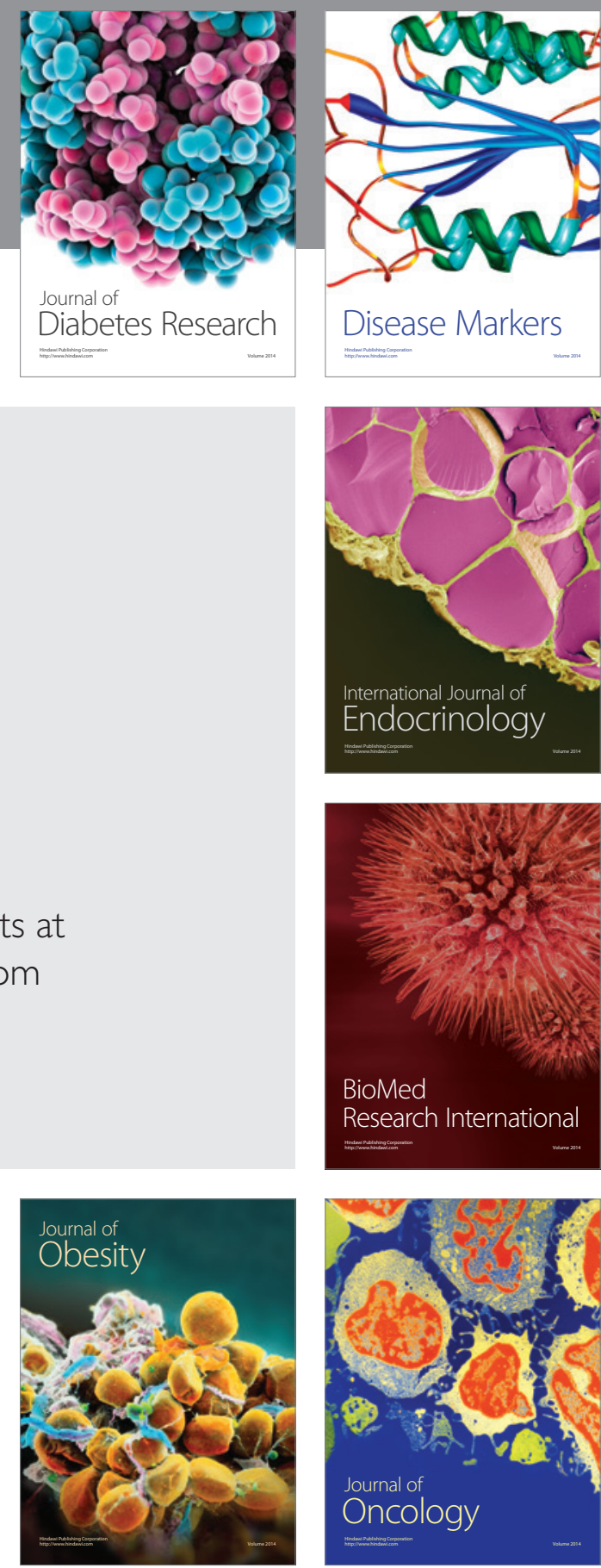

Disease Markers
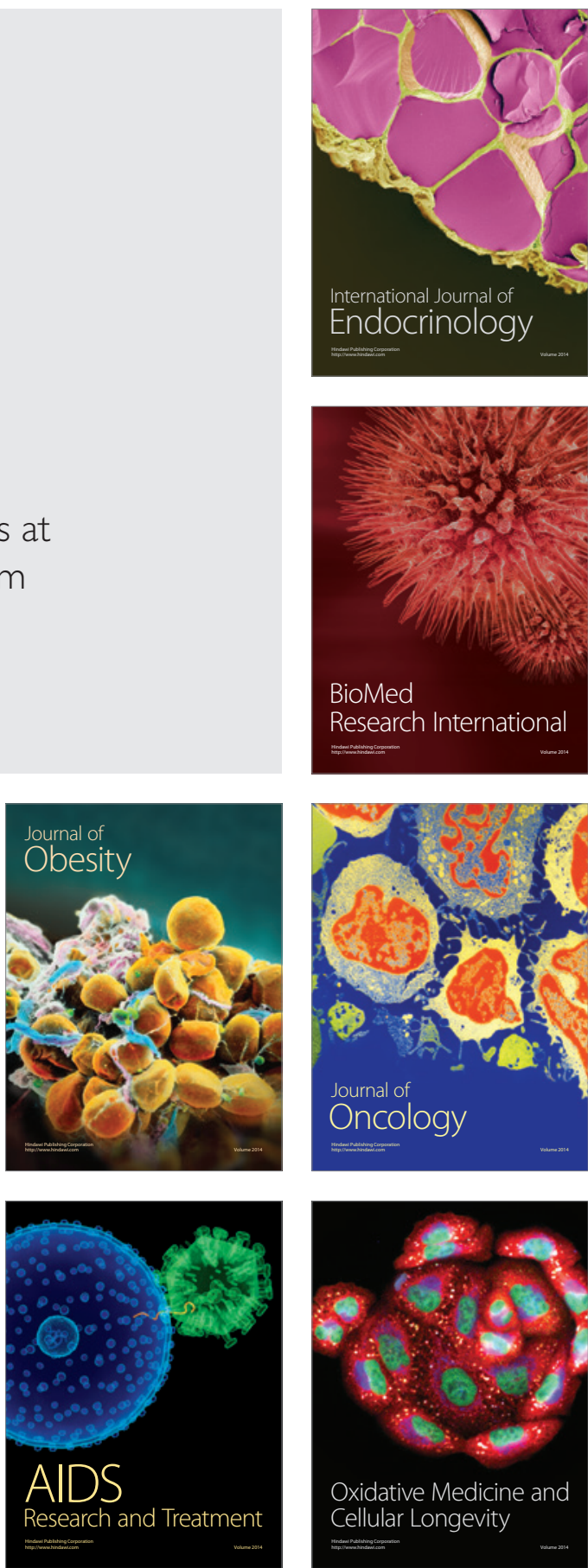